Article

\title{
Endophytic Fungi as Potential Biological Control Agents against Grapevine Trunk Diseases in Alentejo Region
}

\author{
Angela Billar de Almeida ${ }^{1}$, Jonathan Concas ${ }^{2}$, Maria Doroteia Campos ${ }^{1, *(D)}$, \\ Patrick Materatski ${ }^{1}\left(\mathbb{D}\right.$, Carla Varanda ${ }^{1}\left(\mathbb{D}\right.$, , Mariana Patanita ${ }^{1}\left(\mathbb{D}\right.$, Sergio Murolo $^{2}$, \\ Gianfranco Romanazzi ${ }^{2}$ (D) and Maria do Rosário Félix ${ }^{3}$ \\ 1 MED—Mediterranean Institute for Agriculture, Environment and Development, Instituto de Investigação e \\ Formação Avançada (IIFA), Universidade de Évora, Polo da Mitra, Ap. 94, 7006-554 Évora, Portugal; \\ gebillar@gmail.com (A.B.d.A.); pmateratski@uevora.pt (P.M.); carlavaranda@uevora.pt (C.V.); \\ mpatanita@uevora.pt (M.P.) \\ 2 Dipartimento di Scienze Agrarie, Alimentari ed Ambientali, Università Politecnica delle Marche, \\ Via Brecce Bianche, 60131 Ancona, Italy; john.concas@gmail.com (J.C.); s.murolo@staff.univpm.it (S.M.); \\ g.romanazzi@staff.univpm.it (G.R.) \\ 3 MED—Mediterranean Institute for Agriculture, Environment and Development \& Departamento de Fitotecnia, \\ Escola de Ciências e Tecnologia, Universidade de Évora, Pólo da Mitra, Ap. 94, 7006-554 Évora, Portugal; \\ mrff@uevora.pt \\ * Correspondence: mdcc@uevora.pt
}

Received: 26 October 2020; Accepted: 23 November 2020; Published: 26 November 2020

check for updates

Simple Summary: Grapevine trunk diseases are the most widespread fungal diseases, affecting grapevines in all the major growing regions of the world, and their complete eradication is still not possible. Aiming to search alternatives to avoid the spread and high incidence of these diseases, the present work identified in vineyards within the Alentejo region the grapevine fungal community and among it the fungi responsible for those diseases. Grapevine fungal community showed a wide variety of fungi, nine of them previously described as grapevine trunk diseases-associated fungi. Almost all these fungi were detected in symptomatic and asymptomatic plants, which shows the importance of investigating the interactions of fungal communities and confirms the need for early diagnosis of these diseases. The potential of endophytic fungi as bio-control agents was tested against grapevine trunk diseases-associated fungi. These tests were performed among identified endophytes and grapevine trunk diseases phytopathogenic fungi, and all the endophyte fungi showed potential as biocontrol agents. Our findings suggest that endophytes are promising candidates for their use in biological control due to their antagonistic activity against the mycelia growth of grapevine trunk diseases-associated fungi.

Abstract: Grapevine trunk diseases (GTDs) are the most widespread fungal diseases, affecting grapevines in all the major growing regions of the world, and their complete eradication is still not possible. Aiming to search alternatives to avoid the spread and high incidence of these diseases, the present work intended to molecularly identify the grapevine endophytic community, the phytopathogenic fungi associated with GTDs in vineyards within the Alentejo region, and to test potential antagonist microorganisms as biological control candidates against GTDs-associated fungi. Grapevine endophytic community showed a wide variety of fungi in GTDs' asymptomatic and symptomatic plants, nine of them previously described as GTDs-associated fungi. GTDs prevalent fungi identified in symptomatic plants were Diaporthe sp., Neofusicoccum sp., and H. viticola. Almost all these fungi were also detected in asymptomatic plants, which shows the importance of investigating the interactions of fungal communities and confirms the need for early diagnosis of these diseases. Direct inhibition antagonism tests were performed among identified endophytes and GTDs phytopathogenic fungi, and all the 
endophyte fungi showed potential as biocontrol agents. Our findings suggest that endophytes are promising candidates for their use in biological control due to their antagonistic activity against the mycelia growth of some GTDs-associated fungi.

Keywords: grapevine trunk diseases; Vitis vinifera; molecular identification; endophytic fungi; antagonism tests

\section{Introduction}

Grapevine (Vitis vinifera L. and Vitis spp.) belongs to the Vitaceae family and is one of the most economically important woody perennial fruit crops in the world [1]. Nowadays, Portugal is among the twelve major wine producers in the world with a production of 6.1 million hl in 2018 [2] and with the wine consumption growing in the last years. Alentejo (south Portugal) is the second-largest wine producer region of Portugal [3].

Grapevine species are constantly affected by fungal diseases, which cause important economic losses. Grapevine trunk diseases (GTDs) are the most important and destructive fungal diseases, affecting grapevines in all the major growing regions of the world $[1,4,5]$. These destructive diseases cause important damages every year with the need for replacement of dead grapevines worldwide and are the major causes of grapevine decline, especially in European countries [6-8]. GTDs are caused by wood-inhabiting fungi that cause the death of the spurs, canes, and/or cordons in mature and young plants, which impact grape and wine economic production, reducing productivity, quality, and longevity of the vineyards [7,9-14].

GTDs are related to 133 fungal species belonging to 34 different genera and nine different families, with similar life cycles and epidemiology [1,4]. The genera associated with GTDs mostly found worldwide are Botryosphaeria, Diplodia, Lasiodiplodia, Fusicoccum, Neofusicoccum, Dothiorella, Phomopsis, Diaporthe, Eutypa, Eutypella, Diatrypella, Diatrype, Cryptovalsa, Cylindrocarpon, Phaeomoniella, Fomitiporia, Phaeoacremonium, and Greeneria $[5,15,16]$. Grapevines can be infected by different pathogens over the years due to the multiple infection opportunities, and each plant can be affected by one or more GTDs at the same time [1,17].

GTDs-associated fungi live in and colonize the wood of the perennial organs, impeding the water transport in plants by clogging the xylem vessels and, consequently, decrease the adsorption capacity of water and nutrients [18-20]. However, their effect can be undetectable for years due to the slow growth of the pathogens in the vascular tissues, which enables the visibility of symptoms on the canopy [9]. In general, at the time of the appearance of leaf symptoms, the disease has already developed to a severe situation, which can lead, in some cases, to the death of a cordon or of the entire plant [21]. Nevertheless, some plants may remain with leaf symptoms for many years, reaching apoplexy after a heat stress situation [8]. Those fungi may live as endophytes, asymptomatically, during part of their life cycle and, at some point, modify their behavior and become pathogenic, which leads to the expression of the disease symptoms [7]. It is known that several factors may influence the grapevine susceptibility to GTDs, mainly climate, vine age, soil fertilization, rootstock, and cultivar and clones' resistance [22-24].

Since it is known that these diseases are influenced by the type of pathogens involved, and their complete eradication is not possible, the identification, characterization, and early detection of the fungi involved are crucial to an early diagnosis and to the development of efficient control strategies $[14,25,26]$. Therefore, GTDs control is primarily focused on disease prevention and mitigation, based on an integrated management program, including physical, chemical, biological, and/or other control strategies $[1,27]$.

In the past, the impact of GTDs was limited, applying sodium arsenate, which was then prohibited in Europe in 2003 due to its high toxicity on human health and environment [28]. Currently, 
treatments available to control GTDs are not totally efficient [1,17], which leads to the need to search for alternative methods against these diseases. The biological control, based on the use of endophytic microorganisms, has already shown potential and has been the focus of several studies [20,29-31]. The endophytes are defined as microorganisms that colonize healthy internal plant tissues without causing any apparent disease symptoms [32] and may also confer tolerance to environmental stresses and pathogens [33]. The endophytic community in a single plant is usually composed of numerous species of fungi [34], and their number and species composition are influenced by the environment, plant physiology, anthropogenic factors, and pathogen infections [30,35-37]. Therefore, for all the reasons listed before, the knowledge of endophytic communities in grapevine has an important role for future studies on disease management. Fungal endophytes have shown antagonistic effects against grapevine pathogens, such as fungi belonging to the genera Alternaria and Epicoccum against Plasmopara viticola and Botrytis cinerea [38,39]. Other endophytes belonging to the genera Epicoccum, Cladosporium, and Alternaria have revealed their potential as biological control agents against esca-associated fungi $[40,41]$. Besides, fungi like those belonging to the Trichoderma genus have demonstrated efficiency as biological control agents in grapevine. Trichoderma has shown protection of pruning wounds in nurseries [31], reducing the incidence of Phaeomoniella chlamydospora and Phaeoacremonium spp. in rootstock cuttings [42].

The necessity for new strategies against GTDs, the lack of information and data on grapevine endophytic communities in Portugal, especially in a major producing region, such as Alentejo, led to this study, which aimed to (1) identify the fungal endophytic community associated with important grapevine cultivars in Alentejo vineyards; (2) identify the phytopathogenic fungi associated with GTDs in the studied vineyards; (3) acquire new knowledge on the antagonistic interaction among some endophytes and GTDs phytopathogenic fungi.

\section{Materials and Methods}

\subsection{Plant Material}

Assays were carried out in September 2018 in three vineyards located in the Alentejo region (south of Portugal): site 1 ( $\left.38^{\circ} 32^{\prime} 39.32^{\prime \prime} N 7^{\circ} 52^{\prime} 10.6^{\prime \prime} \mathrm{W}\right)$, site $2\left(39^{\circ} 03^{\prime} 00.3^{\prime \prime} \mathrm{N} 7^{\circ} 05^{\prime} 40.2^{\prime \prime} \mathrm{W}\right)$, and site 3 $\left(38^{\circ} 26^{\prime} 42.2^{\prime \prime} \mathrm{N} 7^{\circ} 43^{\prime} 22.8^{\prime \prime} \mathrm{W}\right)$. Roots, petioles, and offshoots of asymptomatic and symptomatic plants were collected from the cultivars Trincadeira (from site 1 and site 2) and Alicante Bouschet (from site 3). Three asymptomatic and three symptomatic plants were sampled from sites 1 and 3 , and five asymptomatic and five symptomatic plants were sampled from site 2 .

From individual plants, eight branches were cut, and secondary roots (length 10-15 cm, diameter 3-5 mm) were collected from different parts of the root system. The root samples were placed into sterile plastic bags along a small portion of soil in order to preserve the humidity. All the samples were transported to the laboratory and stored at $4{ }^{\circ} \mathrm{C}$ until further analyses, which occurred within $48 \mathrm{~h}$. Roots were separated from the soil by washing them in running water and treated with $0.05 \%$ $(v / v)$ Tween 20 in $50 \mathrm{~mL}$ falcon tubes. Roots, petioles, and offshoots samples were decontaminated and treated, according to Spinosi et al. [28].

\subsection{Fungal Isolation}

After decontamination, plant pieces were dried in sterile Whatman paper, cut into sections, placed on Petri dishes of $90 \mathrm{~mm}$ diameter (five per plate) containing Potato Dextrose Agar medium (PDA, Merck, Darmstadt, Germany), and incubated for $1-2$ weeks at $23-25^{\circ} \mathrm{C}$. Each of the different morphologically identified colonies was transferred through a small agar disk (about $5 \mathrm{~mm}^{2}$ ) of the growing fungus to a fresh $60 \mathrm{~mm}$ diameter PDA plate. The obtained colonies were grouped and numbered according to their morphological characteristics, based on shape, form, size, growth time, border, surface, opacity, pigmentation, and the shape and size of the fungal fruiting bodies, spores, 
and hyphae. Hyphae and spores were observed under an Olympus BX-5ed0 compound microscope (400× magnification).

\subsection{Extraction of Genomic DNA ( $g D N A)$}

Once the entire dish surface was covered with the fungus, the mycelium was removed using a sterilized scalpel, and the gDNA was extracted following the CTAB method (hexadecyltrimethylammonium bromide) [43], with some modifications [30]. DNA concentration and quality were determined using a NanoDrop-2000C spectrophotometer (Thermo Scientific, Waltham, MA, USA). Samples were kept in the freezer $\left(-20^{\circ} \mathrm{C}\right)$ until further analyses.

\subsection{Fungal DNA Identification}

The internal transcribed spacer (ITS) region of nuclear rDNA was amplified through PCR from genomic DNA by using ITS1 and ITS4 primers [44]. PCR reactions consisted of $1 \mu \mathrm{L}$ of gDNA, $1.5 \mathrm{mM}$ $\mathrm{MgCl}_{2}, 0.2 \mathrm{mM}$ dNTPs (Fermentas, Thermo Scientific, Waltham, MA, USA), $1 \mathrm{mM}$ of each primer, and 2.5 U of Dream-Taq DNA polymerase (Fermentas, Thermo Scientific, Waltham, MA, USA) in a total reaction volume of $50 \mathrm{~mL}$. Amplification was carried out in a Thermal Cycler (Bio-Rad, Hercules, CA, USA) at $95{ }^{\circ} \mathrm{C}$ for $3 \mathrm{~min}$, followed by 40 cycles of $95^{\circ} \mathrm{C}$ for $30 \mathrm{~s}, 55^{\circ} \mathrm{C}$ for $55 \mathrm{~s}$, and $72{ }^{\circ} \mathrm{C}$ for $2 \mathrm{~min}$ and a final extension at $72{ }^{\circ} \mathrm{C}$ for $10 \mathrm{~min}$. Amplified products were analyzed by $1 \%$ agarose gel electrophoresis prepared with $0.5 \times$ Tris-Borate-EDTA buffer (TBE) and visualized on a Gene Flash Bio Imaging system (Syngene, Cambridge, UK). PCR reaction products were purified using the NZYGelpure kit (Nzytech, Lisbon, Portugal), according to the manufacturer's protocol. Samples were quantified using a spectrophotometer NanoDrop-2000C (Thermo Scientific, Waltham, MA, USA) and sequenced in a sense strand by Macrogen Inc. (Madrid, Spain). ITS sequence homology was explored at the National Center for Biotechnology Information (NCBI) database using the BLAST algorithm (http://www.ncbi.nlm.nih.gov/) (BLASTn). All the fungal sequences that showed resemblance to at least $91 \%$ were used to identify the fungus analyzed.

\subsection{Direct Inhibition Antagonism Test and Multivariate Data Analysis}

The obtained fungal isolates were tested in vitro for their antagonistic activity using the direct opposition method [45], with some modifications. Briefly, a $3 \mathrm{~mm}$ mycelium plug from a pure culture of the potential antagonistic fungus actively growing was placed next to the edge of a $60 \mathrm{~mm}$ PDA dish, and, on the opposite side, a similar-sized mycelial plug of the GTDs pathogen was placed. For this study, six endophytic fungi described as potential antagonists were used [29,30,46-49]: Fusarium oxysporum, Aspergillus niger, Penicillium sp., Trichoderma sp., Clonostachys rosea, and Epicoccum nigrum, and three GTDs pathogens: Diaporthe sp., Phialophora fastigiata, and Diplodia pseudoseriata, totalizing 18 pathogen /antagonist combinations. Each combination of pathogen/antagonist was repeated 3 times as well as the controls, incubating the Petri dishes at $22{ }^{\circ} \mathrm{C} \pm 2{ }^{\circ} \mathrm{C}$, in dark conditions. During the incubation period, the radial growth towards the interacting fungus (internal radius) was measured daily by using a graduated ruler for nine days. Measurements were made from the edge of the plug with the mycelia of the pure culture until the end of the colony growth. The growth of the control fungus was also measured. The inhibition percentage (I) was calculated using the formula: $\mathrm{I}(\%)=100 \times$ [(control - treatment)/control] [50].

The fungal growth values (radial growth in $\mathrm{cm}$ ) were calculated using the fungal growth values dataset from each pathogenic fungus (Diaporthe sp., D. pseudoseriata, and P. fastigiata) in the presence of the potential antagonists (F. oxysporum, A. niger, Penicillium sp., Trichoderma sp., C. rosea, and E. nigrum). In addition, in each assay, the selected fungi were grown without any potential antagonists and values used as a control. A one-way permutational analysis of variance (PERMANOVA) was applied to test the hypothesis that significant differences existed between the growth values of the pathogenic fungi (Diaporthe sp., D. pseudoseriata, and $P$. fastigiata) in the presence of the different potential antagonists (F. oxysporum, A. niger, Penicillium sp., Trichoderma sp., C. rosea, and E. nigrum). 
The PERMANOVA analysis was carried out following the one-factor design: 'Fungal growth' (one level, fixed). Fungal growth values data were square-root transformed to scale down the importance of fungi with high growth and, therefore, increase the importance of the fungi with less growth in the analysis of the similarity between the fungi. The PERMANOVA analysis was conducted on a Bray-Curtis similarity matrix [51]. The null hypothesis was rejected at a significance level $<0.05$ (if the number of permutations was lower than 150, the Monte Carlo permutation $p$ was used). Whenever significant interactions in the effects of the factor were detected, these were examined using posteriori pairwise comparisons, using 9999 permutations under a reduced model.

The statistical analyses were performed using the PRIMER v6 software [52] with the PERMANOVA add-on package [53].

\section{Results}

\subsection{Fungal Isolation from Plant Material}

From the 2681 organisms isolated, 1276 were obtained from asymptomatic plants, 1405 were obtained from symptomatic plants. Most of the isolates were obtained from offshoots (1082 isolates), followed by roots (820 isolates) and petioles (779 isolates) (Table 1). Based on morphological characteristics (shape and size of the fungal fruiting bodies, spores, and hyphae), 39 different fungi were identified, which were selected for molecular identification. Conventional PCR based on the ITS region, followed by sequencing and bioinformatic analysis, confirmed 39 fungi as different individuals, as shown in Table 1. Each isolate was identified as a taxonomic group at the species or genera level; $65 \%$ of the isolates were identified at the species level and $35 \%$ at the genera level.

Table 1. Fungi identified morphologically and molecularly through ITS region, collected in vineyards located in the Alentejo region. The percentage of sequence homology explored at the NCBI database using the BLAST algorithm and the respective number of isolates according to symptomatology and plant organs are indicated.

\begin{tabular}{|c|c|c|c|c|c|c|c|c|c|}
\hline & & \multicolumn{2}{|c|}{ Roots } & \multicolumn{2}{|c|}{ Petioles } & \multicolumn{2}{|c|}{ Offshoots } & \multicolumn{2}{|c|}{ Total } \\
\hline & 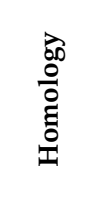 & 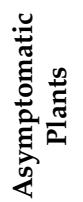 & 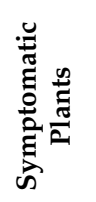 & 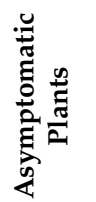 & 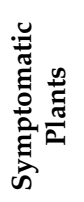 & 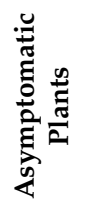 & 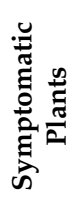 & 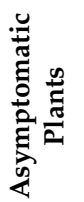 & 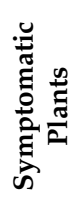 \\
\hline Acrocalymma vagum & $100 \%$ & 0 & 3 & 0 & 0 & 0 & 0 & 0 & 3 \\
\hline Alternaria alternata & $100 \%$ & 2 & 19 & 0 & 14 & 0 & 0 & 2 & 33 \\
\hline Alternaria sp. & $100 \%$ & 21 & 21 & 0 & 8 & 0 & 0 & 21 & 29 \\
\hline Aspergillus niger & $99.47 \%$ & 29 & 16 & 28 & 16 & 22 & 23 & 79 & 55 \\
\hline Aspergillus niveus & $100 \%$ & 0 & 0 & 0 & 1 & 0 & 0 & 0 & 1 \\
\hline Aspergillus sp. & $98.75 \%$ & 0 & 0 & 0 & 1 & 0 & 0 & 0 & 1 \\
\hline Aspergillus terreus & $100 \%$ & 0 & 1 & 0 & 0 & 0 & 0 & 0 & 1 \\
\hline Beauveria bassiana & $98.65 \%$ & 5 & 7 & 5 & 0 & 0 & 0 & 10 & 7 \\
\hline Bjerkandera adusta & $99.14 \%$ & 14 & 20 & 13 & 14 & 23 & 25 & 50 & 59 \\
\hline Botrytis cinerea & $99.50 \%$ & 9 & 26 & 0 & 6 & 1 & 23 & 10 & 55 \\
\hline Chaetomium succineum & $99.71 \%$ & 3 & 0 & 0 & 0 & 0 & 0 & 3 & 0 \\
\hline Clonostachys rosea & $100 \%$ & 11 & 7 & 0 & 4 & 7 & 23 & 18 & 34 \\
\hline Clonostachys sp. & $100 \%$ & 13 & 0 & 0 & 0 & 0 & 11 & 13 & 11 \\
\hline Colletotrichum sp. & $100 \%$ & 1 & 4 & 19 & 16 & 0 & 0 & 20 & 20 \\
\hline Cytospora acaceae & $97.89 \%$ & 0 & 0 & 6 & 0 & 3 & 11 & 9 & 11 \\
\hline
\end{tabular}


Table 1. Cont.

\begin{tabular}{|c|c|c|c|c|c|c|c|c|c|}
\hline & & \multicolumn{2}{|c|}{ Roots } & \multicolumn{2}{|c|}{ Petioles } & \multicolumn{2}{|c|}{ Offshoots } & \multicolumn{2}{|c|}{ Total } \\
\hline & 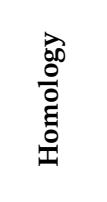 & 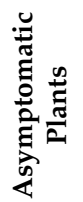 & 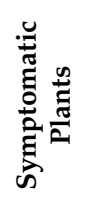 & 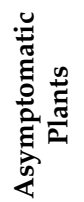 & 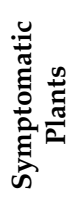 & 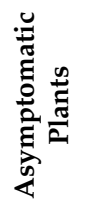 & 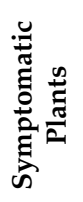 & 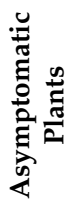 & 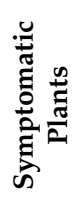 \\
\hline Diaporthe sp. & $99.66 \%$ & 1 & 15 & 4 & 35 & 6 & 47 & 11 & 97 \\
\hline Diplodia pseudoseriata & $100 \%$ & 0 & 0 & 0 & 0 & 1 & 1 & 1 & 1 \\
\hline Epicoccum nigurum & $100 \%$ & 2 & 15 & 7 & 0 & 0 & 1 & 9 & 16 \\
\hline Eupenicillium sp. & $97.89 \%$ & 4 & 0 & 0 & 0 & 0 & 0 & 4 & 0 \\
\hline Fusarium oxysporum & $99.71 \%$ & 21 & 42 & 6 & 50 & 10 & 53 & 37 & 145 \\
\hline Fusarium sp. & $95.25 \%$ & 0 & 10 & 1 & 14 & 10 & 38 & 11 & 62 \\
\hline Fusarium verticillioides & $99.72 \%$ & 1 & 0 & 0 & 0 & 1 & 0 & 2 & 0 \\
\hline Hormonema viticola & $92.05 \%$ & 19 & 29 & 28 & 19 & 6 & 25 & 53 & 73 \\
\hline Macrophomina phaseolina & $100 \%$ & 44 & 19 & 28 & 15 & 30 & 30 & 102 & 64 \\
\hline Neofusicoccum parvum & $98.02 \%$ & 3 & 13 & 5 & 23 & 5 & 26 & 13 & 62 \\
\hline Penicillium chrysogenum & $100 \%$ & 0 & 4 & 0 & 0 & 0 & 0 & 0 & 4 \\
\hline Penicillium glabrum & $91.09 \%$ & 12 & 0 & 25 & 0 & 31 & 0 & 68 & 0 \\
\hline Penicillium sp. & $99.27 \%$ & 59 & 32 & 76 & 98 & 271 & 166 & 406 & 296 \\
\hline Penicillium thomii & $100 \%$ & 17 & 33 & 8 & 12 & 0 & 0 & 25 & 45 \\
\hline Pestalotiopsis sp. & $99.72 \%$ & 0 & 0 & 0 & 0 & 1 & 0 & 1 & 0 \\
\hline Phialophora fastigiata & $99.75 \%$ & 1 & 0 & 0 & 0 & 0 & 0 & 1 & 0 \\
\hline Phialophora sp. & $99.50 \%$ & 0 & 2 & 0 & 0 & 0 & 11 & 0 & 13 \\
\hline Phlebia setulosa & $96.60 \%$ & 2 & 21 & 0 & 0 & 0 & 0 & 2 & 21 \\
\hline Phlebiopsis gigantea & $99.08 \%$ & 4 & 0 & 0 & 0 & 0 & 0 & 4 & 0 \\
\hline Rutstroemiaceae sp. & $100 \%$ & 7 & 0 & 5 & 44 & 2 & 40 & 14 & 84 \\
\hline Stereum armeniacum & $100 \%$ & 4 & 5 & 0 & 0 & 0 & 0 & 4 & 5 \\
\hline Talaromyces sp. & $100 \%$ & 1 & 8 & 0 & 0 & 0 & 0 & 1 & 8 \\
\hline Trichoderma sp. & $99.47 \%$ & 108 & 10 & 88 & 37 & 67 & 31 & 263 & 78 \\
\hline Truncatella angustata & $100 \%$ & 9 & 11 & 0 & 0 & 0 & 0 & 9 & 11 \\
\hline Total & & 427 & 393 & 352 & 427 & 497 & 585 & 1276 & 1405 \\
\hline
\end{tabular}

ITS: Internal Transcribed Spacer; NCBI: National Center for Biotechnology Information; BLAST: Basic Local Alignment Search Tool

The homologous identity score of the fungi performed in NCBI is listed in Table 1 and reveals a high degree of similarity with several fungi species or genera, with $\%$ of homology, which varies from $91 \%$ to $100 \%$. Table 1 also indicates the number of isolates obtained from each fungus species or genera, according to GTDs symptomatology, in each plant organ and in the whole plant.

Through ITS sequencing together with microscopic analysis of morphological characteristics, it was possible to obtain a high diversity of endophytes - seven of them only obtained in asymptomatic plants (Chaetomium succineum, Eupenicillium sp., Fusarium verticillioides, Penicillium glabrum, Pestalotiopsis sp., P. fastigiata, Phlebiopsis gigantea), six only obtained in symptomatic plants (Acrocalymma vagum, Aspergillus niveus, Aspergillus sp., Aspergillus terreus, Penicillium chrysogenum, Phialophora sp.), and 26 obtained in both asymptomatic and symptomatic plants (Alternaria alternata, Alternaria sp., Aspergillus niger, Beauveria bassiana, Bjerkandera adusta, B. cinerea, C. rosea, Clonostachys sp., Colletotrichum sp., Cytospora acaceae, Diaporthe sp., D. pseudoseriata, Epicoccum nigrum, F. oxysporum, Fusarium sp., Hormonema viticola, Macrophomina phaseolina, Neofusicoccum paroum, Penicillium sp., Penicillium thomii, Phlebia setulosa, Rutstroemiaceae sp., Stereum armeniacum, Talaromyces sp., Trichoderma sp., Truncatella angustata) (Table 1). 
Penicillium sp. was the prevalent fungus obtained from the samples, with 702 isolates from asymptomatic and symptomatic plants, followed by Trichoderma sp. with 341 isolates, F. oxysporum with 182 isolates, M. phaseolina with 166 isolates, A. niger with 134 isolates, H. viticola with 126 isolates, B. adusta with 109, and Diaporthe sp. with 108. The remaining fungi showed less than 100 isolates (Table 1).

Penicillium sp. was also the prevalent fungus in both symptomatic and asymptomatic plants, with 406 isolates in asymptomatic plants and 296 in symptomatic plants, mainly obtained from offshoots but also isolated from roots and petioles. Trichoderma sp. isolates were also obtained in a substantially higher number in asymptomatic plants than in symptomatic plants, mainly from the roots. M. phaseolina, A. niger, and P. glabrum also showed a higher number of isolates in asymptomatic than in symptomatic plants. In opposition, the isolates of B. cinerea, Diaporthe sp., F. oxysporum, Fusarium sp., H. viticola, N. parvum, and Rutstroemiaceae sp. were present in a higher number in symptomatic plants than in asymptomatic plants. The other fungi identified presented less than 50 isolates in total (Table 1).

\subsection{Grapevine Trunk Disease (GTDs)-Associated Fungi}

Among the overall fungi that were identified, nine were previously described as GTDs pathogens, with six of them identified at the species level (H. viticola, T. angustata, Stereum armeniacum, P. fastigiata, C. acaciae, D. pseudoseriata) and three at the genera level (Diaporthe sp., Pestalotiopsis sp., Neofusicoccum sp.) (Table 1).

Stereum armeniacum is the only GTD-associated fungus belonging to Division Basidiomycota (Table 2). D. pseudoseriata and N. parvum belong to the Botryosphaeriaceae Family (Table 2). T. angustata and Pestalotiopsis sp. are both from Amphisphaeriaceae Family. Diaporthe sp. and C. acaciae are from Diaportales Order (Table 2).

Table 2. Taxonomy of the GTDs-associated fungi identified in vineyards located in the Alentejo region.

\begin{tabular}{cccccc}
\hline Species/Genus & Genus & Family & Order & Class & Division \\
\hline Hormonema viticola & Hormonema & Dothioraceae & Diaporthales & Sordariomycetes & Ascomycota \\
Truncatella angustata & Truncatella & Amphisphaeriaceae & Xylariales & Sordariomycetes & Ascomycota \\
Stereum armeniacum & Stereum & Stereaceae & Russulales & Agaricomycetes & Basidiomycota \\
Phialophora fastigiata & Phialophora & Herpotrichiellaceae & Chaetothyriomycetidae & Eurotiomycetes & Ascomycota \\
Cytospora acaciae & Cytospora & Valsaceae & Diaporthales & Sordariomycetes & Ascomycota \\
Diplodia pseudoseriata & Diplodia & Botryosphaeriaceae & Botryosphaeriales & Dothideormycetes & Ascomycota \\
Diaporthe sp. & Diaporthe & Diaporthaceae & Diaporthales & Sordariomycetes & Ascomycota \\
Pestalotiopsis sp. & Pestalotiopsis & Amphisphaeriaceae & Xylariales & Sordariomycetes & Ascomycota \\
Neofusicoccum $\mathrm{sp}$. & Neofusicoccum & Botryosphaeriaceae & Botryosphaeriales & Dothideormycetes & Ascomycota \\
\hline
\end{tabular}

GTDs: grapevine trunk diseases.

Overall, almost all GTDs-associated fungi identified belong to Division Ascomycota (eight species/genera), represented by three classes, with the class Sordariomycetes being the most representative (five fungi), followed by the Dothideomycetes (two fungi) and the Eurotiomycetes (one fungus). Only one fungus was identified as belonging to Division Basidiomycota, represented by Class Agaricomycetes (Table 2).

H. viticola was the prevalent fungus in asymptomatic plants (53 isolates), followed by N. parvum (13 isolates) and Diaporthe sp. (11 isolates) (Table 1). The remaining fungi were represented by less than 10 isolates. In the symptomatic plants analyzed, the fungus with the highest number of isolates was Diaporthe sp. (97 isolates), followed by H. viticola (73 isolates), N. parvum (62), C. acacia, and T. angustata (11) (Table 1). Other identified fungi were represented by less than six isolates (Table 1). In general, more GTDs-associated fungal isolates from symptomatic plants were obtained.

T. angustata and S. armeniacum were identified only in roots in both symptomatic and asymptomatic plants. The presence of $H$. viticola was verified in all plant organs of asymptomatic and symptomatic plants, mainly in the petioles of asymptomatic plants with 28 isolates and in the roots of symptomatic plants with 29 isolates. The incidence of Diaporthe sp. was observed mainly in the offshoots of both asymptomatic and symptomatic plants. N. paroum was also verified in all plant organs, in asymptomatic 
and symptomatic plants, and its incidence was mainly observed in offshoots in symptomatic plants. T. angustata was only isolated from roots in both asymptomatic and symptomatic plants (Table 1).

\subsection{Direct Inhibition Antagonism Tests}

Direct inhibition antagonism tests were carried out using three GTDs-associated pathogens, chosen randomly, and six endophytic fungi, which were already reported to have antagonist activity against pathogens.

The fungal growth was observed and measured from the 1st to the 9th day for Diaporthe sp., D. pseudoseriata, and P. fastigiata. PERMANOVA statistical analyses were performed comparing the mycelial growth of the pathogens using the overall measurements from the $3 \mathrm{rd}$, 6th, and 9th day of the tests.

\subsubsection{Evolution of the Control}

By analyzing the growth of the control fungi over the days, it was verified that $P$. fastigiata was the only fungus to reach the edge of the Petri dish (Table 3). However, the mycelia of D. pseudoseriata and E. nigrum grew as fast as the mycelial growth of $P$. fastigiata. Despite the fact that Diaporthe sp. and Penicillium sp. showed mycelial growth only on the third day, A. niger showed less mycelial growth on day 9 within the fungi studied.

Table 3. Growth of the control fungi (in $\mathrm{cm}$ ) over the nine days of the tests (mean values from three replicates).

\begin{tabular}{cccccccccc}
\hline \multirow{2}{*}{ Fungus } & \multicolumn{10}{c}{ Day } \\
\cline { 2 - 10 } & $\mathbf{1}$ & $\mathbf{2}$ & $\mathbf{3}$ & $\mathbf{4}$ & $\mathbf{5}$ & $\mathbf{6}$ & $\mathbf{7}$ & $\mathbf{8}$ & $\mathbf{9}$ \\
\hline Diaporthe sp. & 0 & 0 & 0.67 & 1.50 & 2.83 & 3.80 & 3.80 & 3.80 & 3.80 \\
Diplodia pseudoseriata & 0.70 & 1.53 & 2.83 & 4.00 & 4.00 & 4.00 & 4.00 & 4.00 & 4.00 \\
Phialophora fastigiata & 0.70 & 1.33 & 2.77 & 3.90 & 4.10 & 4.10 & 4.10 & 4.10 & 4.10 \\
Fusarium oxysporum & 0.23 & 0.50 & 0.90 & 1.17 & 1.53 & 1.77 & 2.13 & 2.37 & 2.80 \\
Aspergillus niger & 0.03 & 0.20 & 0.37 & 0.57 & 0.73 & 0.87 & 0.97 & 0.97 & 1.13 \\
Penicillium sp. & 0 & 0 & 0.27 & 0.53 & 0.90 & 1.00 & 1.07 & 1.10 & 1.17 \\
Trichoderma sp. & 0.10 & 0.30 & 0.60 & 0.87 & 1.07 & 1.20 & 1.40 & 1.68 & 1.78 \\
Clonostachys rosea & 0 & 0.30 & 0.80 & 1.07 & 1.57 & 1.67 & 1.97 & 2.05 & 2.30 \\
Epicocum nigrum & 0.43 & 0.70 & 1.23 & 1.70 & 2.20 & 2.73 & 3.17 & 3.70 & 4.03 \\
\hline
\end{tabular}

The growth of Diaporthe sp. started on the 3rd day $(0.67 \mathrm{~cm})$ and stopped on the 6th $(3.80 \mathrm{~cm})$. P. fastigiata started its growth on the 1 st day $(0.70 \mathrm{~cm})$ and stopped it on the 5th day $(4.10 \mathrm{~cm})$, when the margins of the fungus reached the edge of the Petri dish. D. pseudoseriata started its growth on the 1st day $(0.70 \mathrm{~cm})$ and continued growing until the 4 th day $(4.00 \mathrm{~cm})$. F. oxysporum started its growth on the 1 st day $(0.23 \mathrm{~cm})$ and on the 9 th day was still growing $(2.80 \mathrm{~cm})$. The growth of $A$. niger started on the 1st day and on the 9 th reached $1.13 \mathrm{~cm}$. Penicillium sp. had not started growing until the $3 \mathrm{rd}$ day $(0.27 \mathrm{~cm})$ and on the 9 th reached $1.17 \mathrm{~cm}$. Trichoderma sp. had growth from $1 \mathrm{st}(0.10 \mathrm{~cm})$ to 9 th day $(1.78 \mathrm{~cm})$. C. rosea started growing on the 2 nd day $(0.30 \mathrm{~cm})$ and on the 9 th day was still growing $(2.30 \mathrm{~cm}$ ). E. nigrum grew $0.43 \mathrm{~cm}$ on the first day and reached $4.03 \mathrm{~cm}$ on the 9 th (Table 3).

\subsubsection{Antagonistic Action against Diaporthe sp.}

Direct inhibition antagonism tests were carried out to verify the antagonist action of six endophytic fungi against the mycelial growth of Diaporthe sp. All the antagonists were able to inhibit the mycelial growth of the pathogen in the nine days of the direct inhibition test (Figure 1A-C). From the 5th day, there was a deceleration in the mycelial growth of the pathogens caused by the presence of the endophytic fungi when compared to the control. After the 6th day, all radial growth values of Diaporthe sp. were lower than the values of the control (Figure 1A), which was confirmed by statistical analyses (Figure 1B). 


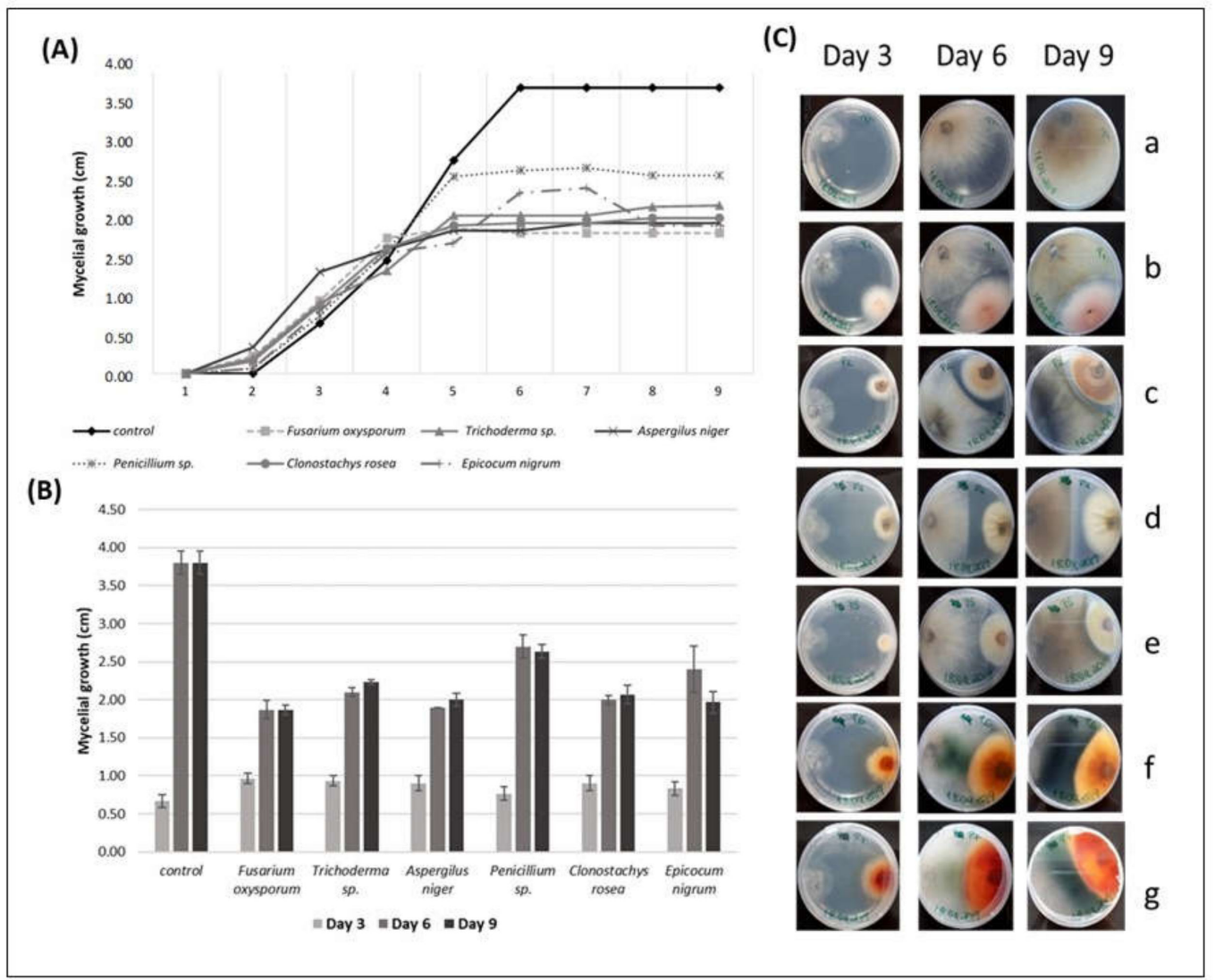

Figure 1. (A) The radial mycelial growth $(\mathrm{cm})$ of Diaporthe sp. over time (days), registered in direct inhibition tests with some endophytic fungi; (B) radial growth values of Diaporthe sp. $(\mathrm{cm})$ (r Diaporthe sp. $\pm \mathrm{SE}$ ) in the presence of different endophytic fungi on the 3rd, 6th, and 9th day of direct antagonism test; (C) interactions of Diaporthe sp., over the days, with grapevine endophytic fungi. Diaporthe sp. on the left side and the endophytic on the right side of the Petri dish. (a) Diaporthe sp. (control), (b) Diaporthe sp. vs. Fusarium oxysporum, (c) Diaporthe sp. vs. Trichoderma sp., (d) Diaporthe sp. vs. Aspergillus niger, (e) Diaporthe sp. vs. Penicillium sp., (f) Diaporthe sp. vs. Clonostachys rosea, (g) Diaporthe sp. vs. Epicocum nigrum. Pictures from the reverse side of the colonies.

The PERMANOVA analysis revealed that the growth of Diaporthe sp. in control was always significantly higher $(p<0.01)$ compared to the Diaporthe sp. growth in the antagonism assay, showing that the mycelial growth of the pathogen did not reach the maximum when in the presence of endophytic fungi (Figure 1A,B). The average growth \pm SE of Diaporthe sp. in the control dish ranged from $0.63 \mathrm{~cm} \pm 0.09$ on the 3rd day to $3.80 \pm 0.15$ on the 9th day.

The average mycelial growth of Diaporthe sp. on the 9th day of the test was $1.87 \mathrm{~cm}$ in the presence of F. oxysporum, which showed the highest antagonistic effect against the pathogen compared to the other fungi in the assay. The mycelial growth of Diaporthe sp. was higher in the presence of Penicillium sp. $(2.63 \mathrm{~cm})$ than in the presence of the other fungi, showing that Penicillium sp. presented the lowest antagonistic effect against the pathogen (Figure 1A). The PERMANOVA analysis also revealed that the mycelial growth of Diaporthe sp. in the presence of Penicillium sp. showed significantly higher values compared to F. oxysporum $(p<0.0052)$, Trichoderma sp. $(p<0.0162)$, A. niger $(p<0.0172)$, and C. rosea $(p<0.0177)$; however, no significant differences $(p>0.05)$ were found when compared to E. nigrum. The mycelial growth of Diaporthe sp., in the presence of $F$. oxysporum, showed no significant differences when compared to A. niger, C. rosea, and E. nigrum ( $p>0.05$ ) (Figure 1B).

The PERMANOVA analysis also revealed no significant differences in the mycelial growth of Diaporthe sp. in the presence of Trichoderma sp. compared to A. niger, C. rosea, and E. nigrum $(p>0.05)$, 
in the presence A. niger compared to $C$. rosea $(p>0.05)$, and in the presence of $C$. rosea compared to E. nigrum (Figure 1B, Table 4).

Table 4. Inhibition of Diaporthe sp., Diplodia pseudoseriata, and Phialophora fastigiata by the endophytic fungus Fusarium oxysporum, Trichoderma sp., Aspergillus niger, Penicillium sp., Clonostachys rosea, and Epicocum nigrum. $p$-values of the one-factor PERMANOVA analysis. Bold values highlight significant differences $(p<0.05)$.

\begin{tabular}{cccc}
\hline & Diaporthe sp. & D. pseudoseriata & P. fastigiata \\
\hline & & $p$-Values & \\
\hline F. oxysporum vs. Control & $\mathbf{0 . 0 0 0 2}$ & $\mathbf{0 . 0 0 0 1}$ & $\mathbf{0 . 0 0 0 5}$ \\
Trichoderma sp. vs. Control & $\mathbf{0 . 0 0 0 2}$ & $\mathbf{0 . 0 0 0 2}$ & $\mathbf{0 . 0 0 2 6}$ \\
A. niger vs. Control & $\mathbf{0 . 0 0 1 4}$ & $\mathbf{0 . 0 0 0 3}$ & $\mathbf{0 . 0 0 0 3}$ \\
Penicillium sp. vs. Control & $\mathbf{0 . 0 0 7 7}$ & $\mathbf{0 . 0 0 0 5}$ & $\mathbf{0 . 0 1 3 1}$ \\
C. rosea vs. Control & $\mathbf{0 . 0 0 1 1}$ & $\mathbf{0 . 0 1 2 6}$ & $\mathbf{0 . 0 0 0 3}$ \\
E. nigrum vs. Control & $\mathbf{0 . 0 0 5}$ & $\mathbf{0 . 0 0 0 8}$ & $\mathbf{0 . 0 0 0 3}$ \\
F.oxysporum vs. Trichoderma sp. & $\mathbf{0 . 0 4 8 5}$ & $\mathbf{0 . 0 3 5 3}$ & 0.386 \\
F. oxysporum vs. A. niger & 0.5766 & $\mathbf{0 . 0 1 7}$ & 0.0566 \\
F. oxysporum vs. Penicillium sp. & $\mathbf{0 . 0 0 5 2}$ & $\mathbf{0 . 0 0 0 6}$ & $\mathbf{0 . 0 3 9 2}$ \\
F. oxysporum vs. C. rosea & 0.3764 & 0.1104 & $\mathbf{0 . 0 2 9 3}$ \\
F. oxysporum vs. E. nigrum & 0.267 & $\mathbf{0 . 0 1 2 3}$ & 0.244 \\
Trichoderma sp. vs. A. niger & 0.1731 & $\mathbf{0 . 0 1 3 7}$ & $\mathbf{0 . 0 3 8 1}$ \\
Trichoderma sp. vs. Penicillium $s p$. & $\mathbf{0 . 0 1 6 2}$ & $\mathbf{0 . 0 0 9 3}$ & 0.1309 \\
Trichoderma sp. vs. C. rosea & 0.3709 & 0.6528 & 0.2162 \\
Trichoderma sp. vs. E. nigrum & 0.6012 & 0.2782 & 0.5927 \\
A. niger vs. Penicillium sp. & $\mathbf{0 . 0 1 7 2}$ & $\mathbf{0 . 0 0 1 1}$ & $\mathbf{0 . 0 0 8 7}$ \\
A. niger vs. C. rosea & 0.7164 & 0.0803 & $\mathbf{0 . 0 0 5 9}$ \\
A. niger vs. E. nigrum & 0.5322 & $\mathbf{0 . 0 1}$ & $\mathbf{0 . 0 2 7 7}$ \\
Penicillium sp. vs. C. rosea & $\mathbf{0 . 0 1 7 7}$ & 0.2489 & 0.1617 \\
Penicillium sp. vs. E. nigrum & 0.1266 & 0.0583 & 0.0757 \\
C. rosea vs. E. nigrum & 0.781 & 0.9857 & 0.1702 \\
\hline
\end{tabular}

During interspecific mycelial interactions, all the endophytic fungi were able to stop the growth of the Diaporthe sp. once they were fighting for space (Figure 1C). Some of them, like Trichoderma sp. and A. niger, did not even touch the pathogen to stop its growth. F. oxysporum, Penicillium sp., C. rosea, and E. nigrum started touching the margins of the pathogen on the 5th day. Changes in the mycelium pigmentation of Diaporthe sp. were also observed during interspecific mycelial interactions. Margins of Diaporthe sp. colonies became lighter brown pigmented in the contact zone with F. oxysporum and dark green pigmented in the contact zone with C. rosea and E. nigrum, which was better observed on the reverse side of the plate (Figure 1C).

\subsubsection{Antagonism Action against Diplodia pseudoseriata}

By analyzing the mycelial growth of D. pseudoseriata over the days, it was verified that from the 3rd day, there was a deceleration in the pathogen growth caused by the presence of the endophytic fungi comparing to the control (Figure $2 \mathrm{~A}-\mathrm{C}$ ). After the 4 th day, all the growth radius values of D. pseudoseriata were lower than the radius values of the control (Figure 2A), which was confirmed by statistical analyses (Figure 2B). 


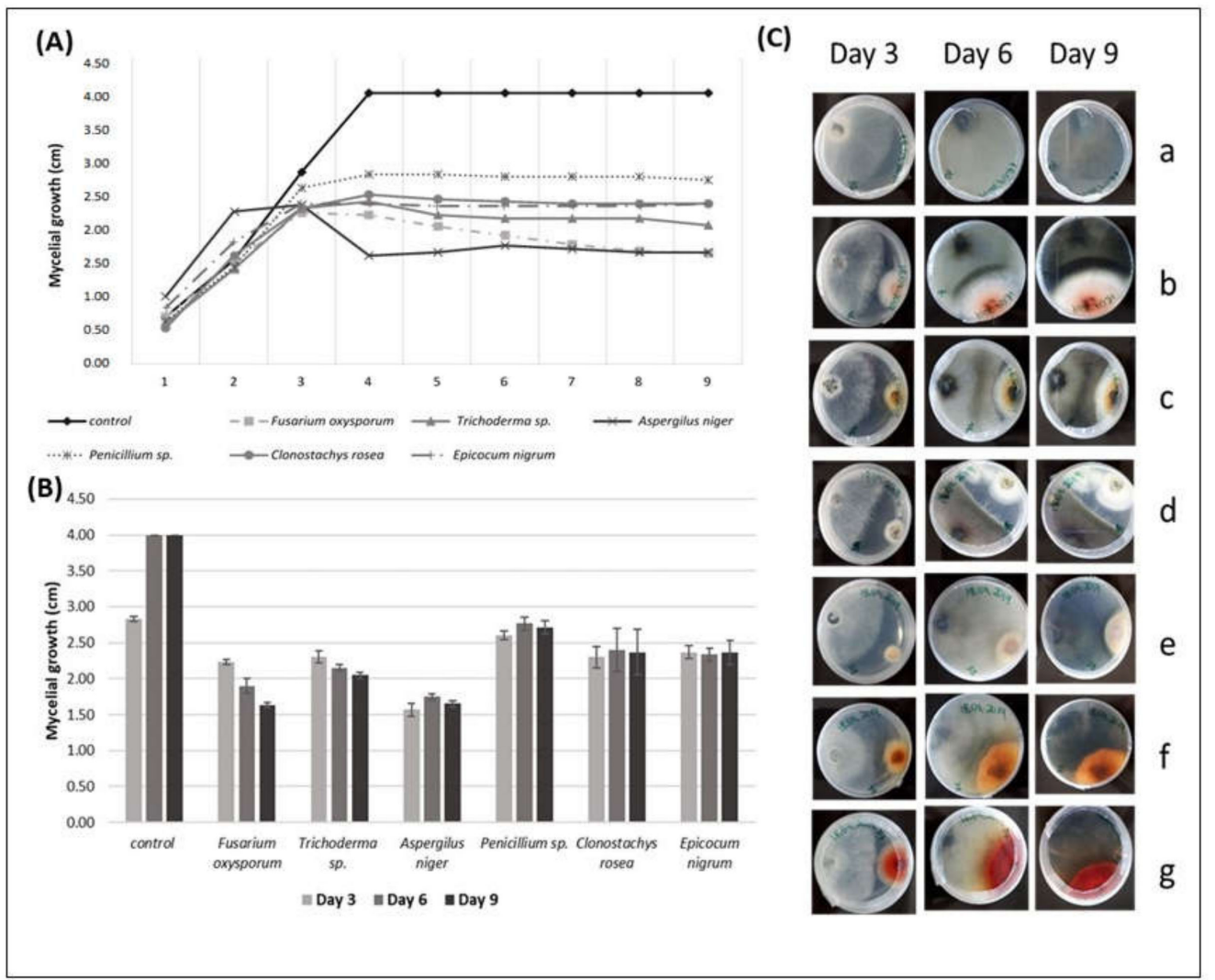

Figure 2. (A) The radial mycelial growth (cm) of Diplodia pseudoseriata over time (days), registered in direct inhibition tests with some endophytic fungi; (B) radial growth values of Diplodia pseudoseriata $(\mathrm{cm})(\mathrm{r}$ D. pseudoseriata $\pm \mathrm{SE}$ ) in the presence of different endophytic fungi on the 3rd, 6th, and 9th day of direct antagonism test; (C) interactions of Diplodia pseudoseriata, over the days, with grapevine endophytic fungi. Diplodia pseudoseriata on the left side and the endophytic on the right side of the Petri dish. (a) Diplodia pseudoseriata (control), (b) Diplodia pseudoseriata vs. Fusarium oxysporum, (c) Diplodia pseudoseriata vs. Trichoderma sp., (d) Diplodia pseudoseriata vs. Aspergillus niger, (e) Diplodia pseudoseriata vs. Penicillium sp., (f) Diplodia pseudoseriata vs. Clonostachys rosea, (g) Diplodia pseudoseriata vs. Epicocum nigrum. Pictures from the reverse side of the colonies.

The mycelial growth of $F$. oxysporum showed the highest antagonistic effect against $D$. pseudoseriata compared to the other fungi in the test, once the average mycelial growth of the pathogen on the 9th day of the test was $1.63 \mathrm{~cm}$ against the control's average of $4.00 \mathrm{~cm}$.

The mycelial growth of D. pseudoseriata was higher in the presence of Penicillium sp. $(2.72 \mathrm{~cm})$ than in the presence of the other fungi, confirming that Penicillium sp. showed the lowest antagonistic effect against this pathogen (Figure 2A).

The PERMANOVA analysis revealed that the mycelial growth of $D$. pseudoseriata in the presence of F. oxysporum showed significantly lower values compared to A. niger $(p<0.017)$, E. nigrum $(p<0.0123)$, and Trichoderma sp. $(p<0.0353)$; however, it showed no significant differences when compared to C. rosea $(p>0.05)$.

Trichoderma sp. in the presence of $D$. pseudoseriata showed significantly lower mycelial growth values compared to $A$. niger $(p<0.0137)$ and no significant differences compared to $C$. rosea $(p>0.05)$. The mycelial growth of $D$. pseudoseriata in the presence of Penicillium sp. showed significantly higher values compared to F. oxysporum ( $p<0.0006)$, Trichoderma sp. $(p<0.0093)$, and A. niger $(p<0.0011)$; however, no significant differences were obtained when compared to E. nigrum ( $p>0.05)$. E. nigrum showed significantly lower values of the mycelial growth of D. pseudoseriata compared to A. niger 
$(p<0.01)$ but showed no significant differences when compared to Trichoderma sp. and C. rosea (Figure 2B, Table 4).

The mycelial growth of $D$. pseudoseriata was stopped by all the endophytic fungi studied in the antagonism tests. However, the endophytic fungus $A$. niger did not even touch the pathogen to stop its growth. E. nigrum started touching the margins of the pathogen on the 3rd day; F. oxysporum and Penicillium sp. on the 4th day; C. rosea on the 5th day, and Trichoderma sp. on the 6th day. Changes in the mycelium pigmentation of $D$. pseudoseriata were also observed during interspecific mycelial interactions. The colony of $D$. pseudoseriata did not change color when interacting with Penicillium sp. In all the other interactions, the colonies of Diplodia pseudoseriata became dark brown (Figure 2C).

\subsubsection{Antagonism Action against Phialophora fastigiata}

By analyzing the mycelial growth of $P$. fastigiata over the days, a deceleration in the pathogen growth from the 3rd day was verified compared to the control, caused by the presence of the endophytic fungi. After the 4th day, all the radial growth of $P$. fastigiata was lower than the radius values of the control (Figure 3A). The PERMANOVA analysis revealed that the mycelial growth of $P$. fastigiata in control was always significantly higher $(p<0.01)$ compared to the $P$. fastigiata used in the antagonism assays (Figure 3B).

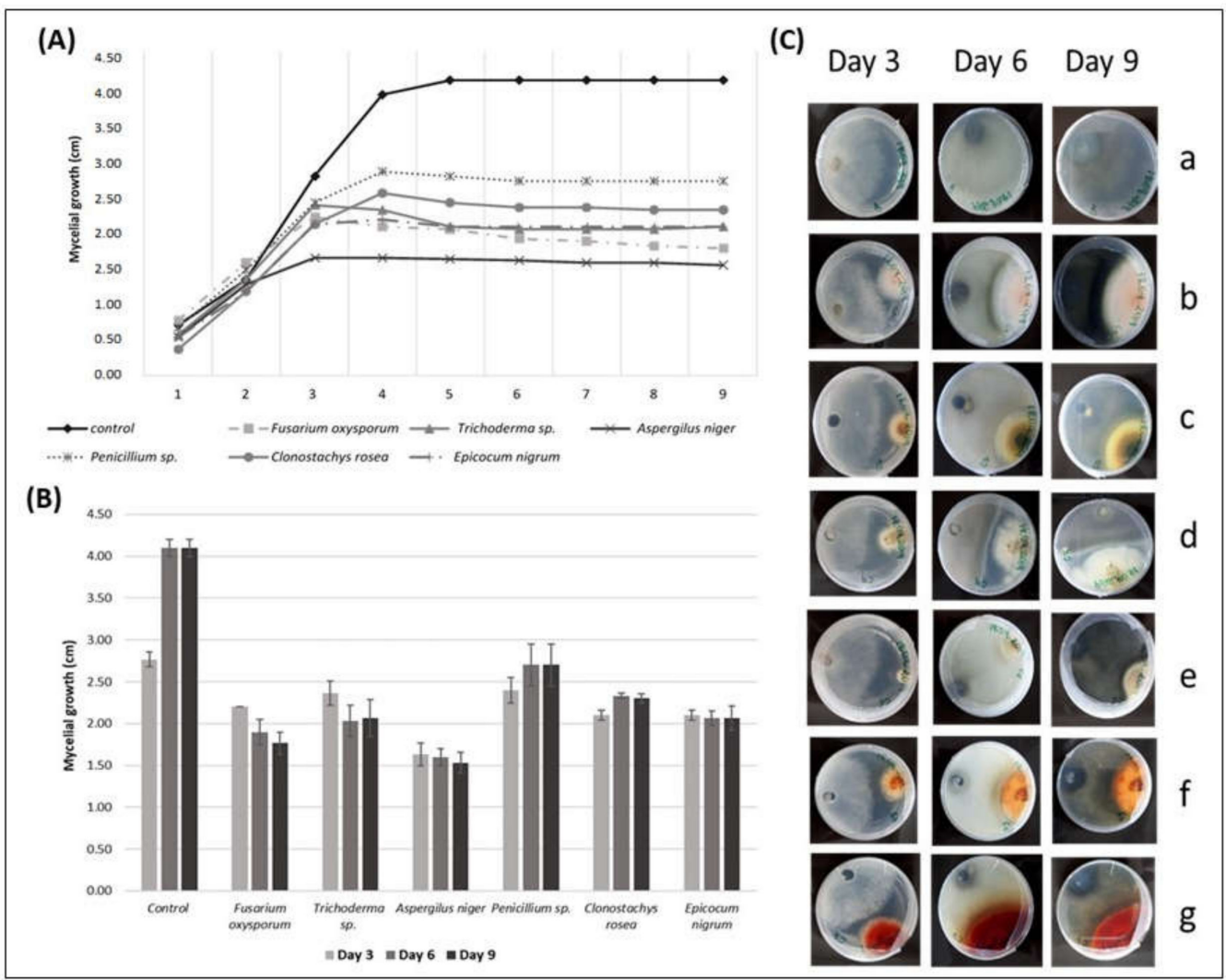

Figure 3. (A) The radial mycelial growth (cm) of Phialophora fastigiata over time (days), registered in direct inhibition tests with some endophytic fungi; (B) radial growth values of $P$. fastigiata $(\mathrm{cm})$ ( $\mathrm{r}$ P. fastigiata $\pm \mathrm{SE}$ ) in the presence of different endophytic fungi on the 3rd, 6th, and 9th day of direct antagonism test; (C) interactions of $P$. fastigiata, over the days, with grapevine endophytic fungi. $P$. fastigiata on the left side and the endophytic on the right side of the Petri dish. (a) $P$. fastigiata (control), (b) P. fastigiata vs. Fusarium oxysporum, (c) P. fastigiata vs. Trichoderma sp., (d) P. fastigiata vs. Aspergillus niger, (e) P. fastigiata vs. Penicillium sp., (f) P. fastigiata vs. Clonostachys rosea, (g) P. fastigiata vs. Epicocum nigrum. Pictures from the reverse side of the colonies. 
The average mycelial growth of $P$. fastigiata on the 9th day of the test was $1.53 \mathrm{~cm}$ in the presence of $A$. niger, which showed the highest antagonistic effect against the mycelial growth of the pathogen compared to the other fungi in the test. On the other hand, Penicillium sp. showed the lowest antagonistic effect in the growth of the mycelia of P. fastigiata, which reached $2.70 \mathrm{~cm}$ in the presence of this fungus (Figure 3A).

In addition, PERMANOVA analysis revealed that the mycelial growth of $P$. fastigiata in the presence of Penicillium sp. showed significantly higher values when compared to F. oxysporum $(p<0.0392)$ and to $A$. niger $(p<0.0087)$. The mycelial growth of $P$. fastigiata in the presence of $A$. niger showed significantly lower values when compared to C. rosea $(p<0.0059)$, E. nigrum $(p<0.0277)$, and Trichoderma sp. $(p<0.0381)$. F. oxysporum showed a significantly lower antagonistic effect compared to $C$. rosea $(p<0.0293)$.

The PERMANOVA analysis also revealed no significant differences between the remaining fungi $(p>0.05)$ : F. oxysporum vs. Trichoderma sp., F. oxysporum vs. A. niger, F. oxysporum vs. Penicillium sp., F. oxysporum vs. C. rosea, F. oxysporum vs. E. nigrum, Trichoderma sp. vs. A. niger, Trichoderma sp. vs. Penicillium sp., Trichoderma sp. vs. C. rosea, Trichoderma sp. vs. E. nigrum, Penicillium sp. vs. C. rosea, Penicillium sp. vs. E. nigrum, and C. rosea vs. E. nigrum (Figure 3B).

The mycelial growth of $P$. fastigiata was stopped by all the endophytic fungi studied in the antagonism tests once they were fighting for space. In all interactions, the pathogen touched the margins of the endophytic fungi. All the endophytes started the mycelial growth on the first day; only A. niger mycelia did not start growing until the second day. F. oxysporum started touching the margins of the pathogen on the 3rd day; Trichoderma sp. and E. nigrum on the 4th day; Penicillium sp. and C. rosea on the 5th day, and Trichoderma sp. on the 8th day (Figure 3B, Table 4).

Changes in the mycelium pigmentation of $P$. fastigiata were observed during interspecific mycelial interactions. The pathogen did not change color only in the interaction with Trichoderma sp. In all the other interactions, the colonies of P. fastigiata became dark brown (Figure 3C).

\subsubsection{The Growth Inhibition of GTDs-Associated Fungi}

The growth inhibition percentage of Diaporthe sp., D. pseudoseriata, and P. fastigiata was calculated on the 9th day of the direct inhibition test, using the formula described above. The inhibition percentages calculated for fungal isolates ranged from $30.70 \%$ to $62.60 \%$ (Table 5), showing that all endophytic fungi had some inhibitory action against the growth of the GTDs-associated fungi used in the tests. Penicillium sp. showed the lowest inhibition percentages values against the mycelial growth of Diaporthe sp., D. pseudoseriata, and P. fastigiata, ranging between $30.70 \%$ and $34.15 \%$ (Table 5), confirming the results described above. F. oxysporum showed the highest inhibition percentages values against Diaporthe sp. (50.88\%) and D. pseudoseriata (59.17\%), confirming the results already described. A. niger presented the highest antagonistic effect against $P$. fastigiata, with inhibition percentages of $62.60 \%$ (Table 5).

Table 5. Inhibition percentages of Diaporthe sp., Diplodia pseudoseriata, and Phialophora fastigiata by the endophytic fungus Fusarium oxysporum, Trichoderma sp., Aspergillus niger, Penicillium sp., Clonostachys rosea, and Epicocum nigrum, calculated 9 days after inoculation.

\begin{tabular}{cccc}
\hline & \multicolumn{3}{c}{ Inhibition Percentage } \\
\hline & Diaporthe sp. & D. pseudoseriata & P. fastigiata \\
\hline F. oxysporum & $50.88 \%$ & $59.17 \%$ & $56.91 \%$ \\
Trichoderma sp. & $41.23 \%$ & $48.75 \%$ & $49.59 \%$ \\
A. niger & $47.37 \%$ & $58.75 \%$ & $62.60 \%$ \\
Penicillium sp. & $30.70 \%$ & $32.08 \%$ & $34.15 \%$ \\
C. rosea & $45.61 \%$ & $40.83 \%$ & $43.90 \%$ \\
E. nigrum & $48.25 \%$ & $40.83 \%$ & $49.59 \%$ \\
\hline
\end{tabular}




\section{Discussion}

\subsection{Fungi Identification}

Samples were collected from three different parts of plants (roots, petioles, and outshoots) showing GTDs symptoms (symptomatic plants) and from plants without GTDs symptoms (asymptomatic plants). The chosen cultivars for the study are important and representative cultivars for wine production from the Alentejo region as Trincadeira and Alicante Bouschet. These cultivars are included in the list of the ones allowed for wine production with the European nomenclature of Protected Designation of Origin (PDO), with several studies performed on their susceptibility to different pathogens and resistance to diseases.

In total, 2681 organisms were isolated from the samples, with fungal-like morphological characteristics. The fungi isolated were grouped based on morphological characteristics, which allowed the identification of 39 different molecular different individuals.

Despite the fact that the ITS region has a low taxonomic resolution for some species delimitations, mainly in some highly speciose genera, such as Aspergillus, Cladosporium, Fusarium, Penicillium, and Trichoderma [54,55], it is the main genetic marker for molecular identification at the species level and can be very suitable in some situations [56], as in the present study, where $67.5 \%$ of the individuals were identified at the species level, which was enough for the study proposes. Moreover, the molecular characterization through the ITS region corroborated the results achieved with the morphological identification.

\subsubsection{Endophytes Fungal Community}

Most of the isolates were obtained from offshoots (1082 isolates), followed by roots ( 820 isolates) and petioles (779 isolates). From the total organisms isolated, 1276 were obtained from asymptomatic plants, 1405 were obtained from symptomatic plants. In a total of 39 different endophytic fungi identified, 26 were obtained from both asymptomatic and symptomatic plants, seven of them were only obtained from asymptomatic plants (C. succineum, Eupenicillium sp., F. verticillioides, P. glabrum, Pestalotiopsis sp., P. fastigiata, P. gigantea), and six were only obtained from symptomatic plants (A. vagum, A. niveus, Aspergillus sp., A. terreus, P. chrysogenum, Phialophora sp.).

The identification of endophytic fungal community is essential to determine the endophyte distribution in the vineyard to understand the role of the communities on the host and their influence in wine characteristics, for example, and to analyze their relationship with plant pathogens or diseases [57]. Most endophytes reside in the plant tissues without causing any effect on the host. Some of them can have mutualistic relationships with plants; others can provide benefits to their host through the promotion of plant growth and biocontrol against plant pathogens. Nevertheless, when environmental conditions become favorable, some endophytes may also exhibit pathogenic activity [58]. The importance to identify the endophytic fungal communities in the grapevines comes not only to identify some fungi in the plant, which can interfere in the wine quality through the production of toxic metabolites, such as fungi belonging to Aspergillus and Penicillium genera [30], but also to understand their relationships with known pathogens, so that control strategies may be developed.

Fungi belonging to Fusarium, Penicillium, Alternaria, and Botryosphaeria genera are referred to as the dominant endophytic fungi found in grapevine plants [59]. In this study, Penicillium sp. was the prevalent fungus, with 702 isolates-406 isolates obtained from asymptomatic plants and 296 from symptomatic plants. Penicillium sp. were mainly isolated from offshoots; however, they were also isolated from roots and petioles. Fungi belonging to Penicillium genera are the most common fungi reported in soil, air, and plants, playing the role of saprophytes or endophytes [60].

Limited studies can be found on the grapevine endophytic microbial community, with most researches focusing on bacterial endophytes [61]. In Alentejo vineyards, an endophytic community study was already performed by Varanda et al. [30], who identified 240 isolates belonging to 16 
operational taxonomical units (OTUs), which is substantially less in number and in the variability of the endophytic community than the isolates obtained in the present work. Nevertheless, it is important to consider that different factors can shape the grapevine microbiome, such as seasonality, plant genotype, age, pedo-climatic features, surrounding wild plants, presence of a pathogen, the variety of the host plant, and others [57].

\subsubsection{GTDs-Associated Fungi}

In the study presented here, among the 39 fungi identified morphologically and by molecular techniques, nine were associated with GTDs, with six identified at the species level (H. viticola, T. angustata, S. armeniacum, P. fastigiata, C. acaciae, D. pseudoseriata) and three at genera level (Diaporthe sp., Pestalotiopsis sp., Neofusicoccum sp.).

GTDs are primarily caused by ascomycetous fungi. However, some basideomiceteous taxa are also thought to play an important role in this disease complex [1,62], such as $S$. armeniacum from the Stereaceae family, the only fungus belonging to the Basidiomycota Division identified in this study. Among the ascomycetous identified in this work, two belong to the Botryosphaeriaceae family, two to Dothioraceae, two to Amphisphaeriaceae, one to Herpotrichiellaceae, and one to Valsaceae.

Fungi from the Botryosphaeriaceae family can cause cankers and consequent dieback in the most important grape growing areas in the world and are associated with the disease "Botryosphaeria dieback" of grapevines [63]. Diplodia pseudoseriata and N. parvum, identified in this work, are two of the most frequently isolated Botryosphaeriaceae fungi in grapevine areas worldwide [25].

H. viticola and Diaporthe sp. belong to the Dothioraceae family. H. viticola is a new fungus associated with GTDs, and it was first identified in the Canary Islands from the grapes in Vitis vinifera cv. Malvasia [64]. The generic names Diaporthe and Phomopsis are no longer used to distinguish different morphs of this genus, and Diaporthe is the denomination used nowadays $[65,66]$. Pathogenicity of several Phomopsis spp./Diaporthe spp., including Phomopsis viticola (Ascomycota, Diaporthales; syn. = Diaporthe ampelina), on grapevines has been well-established on green shoots of new vegetative growth [67]; however, it is now clear that Phomopsis viticola can be also associated with cankers in addition to the green parts of the grapevines [63], and this fungus is the principal pathogen associated with "Phomopsis dieback disease" [68].

T. angustata and Pestalotiopsis sp., commonly known as pestalotioid, belong to the Amphisphaeriaceae family and have been reported from grapevines with decline symptoms [69]. Pestalotiopsis sp. and Truncatella sp. are associated with grapevine cankers in Texas. The pathogenicity of a Truncatella sp. has shown low virulence and low percentage recovery from necrotic tissue, indicating that this species may act as a weak and/or opportunistic pathogen on grapevine [63]. P. fastigiata, originally described as Cadophora fastigiata [70], belongs to the Herpotrichiellaceae family, and it is associated with the decline of grapevines and has been reported from many grapevines growing countries, causing wood lesions and black streaking in longitudinal stem sections, the typical internal symptoms of esca and Petri disease [71]. C. acaciae belongs to the genus Cytospora, the family Valsacea. Cytospora sp. canker shows some of the same general dieback-type symptoms as botryosphaeria, eutypa, and phomopsis diebacks, placing these fungi in the GTDs complex [72].

In the present study, it was possible to identify GTDs pathogens in symptomatic and asymptomatic plants. Environmental conditions can activate virulence factors, leading to the pathogenicity of fungi due to the alteration of plant-fungus balance [73], resulting in disease in the host. Plant diseases may result from continuous irritation generated by a pathogen, which causes malfunction of host cells and their tissues [74], and it leads to the development of symptoms. However, if the environmental conditions are not favorable, and the pathogenicity of the fungus is not activated, the fungus can enter a latent state and remain inside the host without causing any symptoms [75]. The presence of antagonistic microorganisms can also difficult the development of the disease, stopping the colonization of the pathogen by the competition for nutrition and space or by the production of secondary metabolites that inhibit fungal growth $[29,76]$. 
In this study, the most commonly identified fungus associated with GTDs in asymptomatic plants was $H$. viticola, present in all plant tissues. However, the highest incidence of this fungus in asymptomatic plants was observed in the petioles of the plants. The incidence of fungi belonging to the Diaporthe genera in asymptomatic plants was not high; however, it was possible to identify them in the three areas, in the two cultivars, and in all plant organs studied. Diaporthe spp. comprises pathogenic, endophytic, and saprophyte species [77]; therefore, fungi from this genus are frequently present in asymptomatic plant tissues [78]. Even though there is a lack of information about H. viticola, especially linked to grapevine plants, this fungus belongs to the same family as Diaporthe, which can be an interesting beginning for future studies. Neofusicoccum species, T. angustata, S. armeniacum, C. acaciae were verified in asymptomatic plants. Once inside the host, endophytes enter a latent state [75], which can be the main reason for the late onset of symptoms caused by the infection of GTDs pathogens. Plant-endophyte balance can be altered by environmental conditions, which can activate virulence factors, leading to the pathogenicity of the fungus [73], which explains the presence of phytopathogenic fungi, identified also inside asymptomatic plants [30].

In symptomatic plants, the predominant GTDs-associated fungi in the three areas studied were Diaporthe sp., H. viticola, and the fungi associated with Neofusicoccum genera. Phomopsis viticola is also one of the predominant species identified in a field study in several vineyards in Portugal [79]. The fungus $P$. fastigiata was identified in symptomatic plants of Trincadeira cultivar. T. angustata, S. armeniacum, C. acaciae, D. pseudoseriata, and the fungi from Pestalotiopsis genera were identified on only a few occasions.

GTDs pathogens were verified in all plant organs; however, their incidence in the organs showed differences since vascular fungi like GTDs pathogens do not colonize systemically [80]. In other words, once inside the plant, vascular fungi responsible for cankers colonize the organ, which is infected, and their spores do not spread throughout the plant. Diaporthe sp. was the only fungus whose incidence was observed similarly in asymptomatic and symptomatic plants, with the offshoot the most infected organ, followed by petiole and root, respectively, showing that the infection of the pathogen in the plant could possibly have happened mainly through pruning wounds $[1,18,80]$. Even though GTDs-associated fungi infections happen primarily by pruning wound, the infection by those pathogens can also happen through any type of open wounds, such as those caused by retraining, trimming, and de-suckering [81], which can possibly explain the identification of GTDs-associated fungi in different organs of the plants. Some GTDs pathogens, like fungi responsible for black foot, are soilborne and are commonly found in nursery fields and soils; therefore, inoculum may already exist in soils before plantation, and infection can happen by some wounds caused by culture management [1], which explains the incidence of some phytopathogens in roots, such as T. angustata and S. armeniacum, verified only in the roots of both asymptomatic and symptomatic plants.

\subsection{Endophyte Antagonism Activity}

To provide efficient control against GTDs, researchers and specialists have been waging in control techniques set, which can involve also biological alternatives. Biological control against fungi has been studied in the last decades, and some researchers believe that it can be a good alternative to maintain GTDs-associated fungi under control. Several studies have shown that some fungal endophytes have beneficial effects on their hosts, such as in grapevines, showing antagonistic properties against some important pathogens [30]. Antagonist microorganisms can be used as biological control agents, contributing to achieving productive and sustainable agriculture. Thus, the investigation has been conducted on the diversity, distribution, and influence of endophytic fungi on the development and/or prevention of certain fungal diseases [46].

With the present work, we aimed to identify and study the GTDs-associated fungi with the intention of contributing to alternatives for reducing the incidence of these diseases. Thus, a better understanding of the role of endophytes in this GTDs complex was pertinent. The wide variety of endophytic fungi identified in this research led to a study of the interaction between possible 
antagonistic endophytes and GTDs phytopathogenic-associated fungi, as a starting point for the development of a biological control method. Therefore, direct inhibition antagonism was tested in vitro, using fungi identified in this research: three GTDs phytopathogenic (Diaporthe sp., P. fastigiata, and D. pseudoseriata) and six potential antagonistic endophytes (F. oxysporum, A. niger, Penicillium sp., Trichoderma sp., C. rosea, and E. nigrum).

All the endophytes used for the direct inhibition antagonism tests were able to negatively affect the growth of the GTDs-associated fungi, showing that non-pathogenic microorganisms can possibly protect hosts through their competition with phytopathogen for space and nutritional resources. However, it is not possible to confirm that the competition is the only mechanism responsible for the pathogen growth inhibition, once the antagonistic properties of biocontrol agents are based on the activation of multiple mechanisms, such as the competition for nutrients and space, mycoparasitism, antibiosis, metabolite production, or volatile compounds production [29,46,82].

A. niger was the only fungus that did not even touch the mycelium of the pathogen Diaporthe sp. and D. pseudoseriata; nevertheless, it still stopped the mycelium growth of those pathogens. The growth-inhibitory effects before physical contact between fungi may suggest the antagonistic mode of action that can also occur due to the production of certain metabolites by endophytic fungi, rather than just competition or parasitism [83].

On the 9th day of the test, inhibition percentages were calculated based on the control of each phytopathogen. F. oxysporum showed the highest percentage inhibition rate on the mycelial growth of Diaporthe sp. and D. pseudoseriata, and it presented the inhibition rates above $50 \%$ of the mycelial growth of $P$. fastigiata. In this study, the number of isolates of $F$. oxysporum obtained from symptomatic plants (145 isolates) was higher than obtained from asymptomatic (37 isolates). Although the number of $F$. oxysporum isolates increased, this fungus did not seem to help to inhibit the increase of the growth of Diaporthe sp. on symptomatic (97 isolates) compared to asymptomatic plants (11 isolates). Fusarium species have been reported to have antagonistic activity against Colletotrichum acutatum in olives trees [29]. However, some strains of F. oxysporum are known to be soil pathogens and responsible for grapevine decline and death $[84,85]$.

Many antagonistic microorganisms have been proved to be active in vitro or in vivo. Among this list, the most well-known are the fungi from genera Trichoderma, Aspergillus, and Penicillium [48]. A. niger was the most potent inhibitor for the mycelium growth of $P$. fastigiata (62.60\%), even if its mycelia only started growing on the second day, and it showed a slow mycelial growth over the days. However, in this study, the number of $A$. niger isolates from asymptomatic plants (79) was higher than from symptomatic plants (55). The success of antagonistic activity of $A$. niger has been confirmed in a study with Colletotrichum acutatum from olive trees, and the antagonistic efficiency has been assigned to the rapid growth and competition for space/nutrients, which is the opposite result showed in the study mentioned in the sentence below [29].

Although Penicillium spp. was the most abundant fungus in the present work, it demonstrated to be the least efficient antagonism fungus against the growth of the three GTDs pathogens, with inhibition rates between $30 \%$ and $35 \%$. The number of Penicillium sp. isolates was higher in asymptomatic plants (406 isolates) than in symptomatic (296 isolates), which could be affected by the growth of other fungi or environmental conditions. However, fungi belonging to this species are considered to have interesting antagonistic activity against diverse pathogenic fungi due to the production of secondary metabolites with antibiotic activity [46]. They have the capacity to produce bioactive secondary metabolites, which has been stimulating researchers to investigate their involvement in plant protection based on a possible induction of antagonistic effects toward plant pathogens [61]. Many Penicillium species have been reported having antagonistic effects against plant pathogens using the induction of resistance, the production of antibiotic compounds, and the establishment of mycoparasitic interactions as mechanisms of action [86].

Trichoderma spp. are the most widely studied biological control agents for root and shoot pathogens to combat a wide range of plant diseases [87]. In this study, Trichoderma sp. was the second most 
abundant fungus, and it showed an effective effect in the pathogen's growth inhibition, with mycelial inhibition rates under $50 \%$ in all tests. As expected, the number of Trichoderma sp. isolates was higher in asymptomatic plants (263 isolates) than in symptomatic (78 isolates), which could affect the growth of other fungi, such as GTDs pathogens. Trichoderma-based biocontrol mechanisms are mainly relying on mycoparasitism, production of antibiotic and/or hydrolytic enzymes, competition for nutrients, as well as induced plant resistance and numerous secondary metabolites, which can act directly or indirectly against the targeted pathogens of cultivated and forestry plants $[49,88]$.

C. rosea and E. nigrum presented inhibition percentages around $40 \%$ and $50 \%$ in the mycelia growth of all pathogens studied. Both fungi showed a higher number of isolates in symptomatic plants than in asymptomatic. Epicoccum species have also shown antagonism activity against some grapevine phytopathogens like P. viticola and B. cinerea [30]. E. nigrum has been studied as a promising biocontrol agent and has been developed commercially due to its capability to produce secondary metabolites with antibiotic activity [89]. C. rosea has already been used as a biological agent in some crops. This biocontrol agent acts by two forms of antagonism: parasitism of hypha and competition for space and nutrition. During parasitism, the antagonistic fungus can remove pathogenic hyphae from the substrate and the previously colonized tissues [47].

Changes in pathogen mycelium pigmentation were observed during almost all interspecific mycelial interactions. Diaporthe sp. changed mycelium pigmentation from light brown to almost black when in contact with Trichoderma sp. Diaporthe sp. mycelium also changed pigmentation from light brown to dark-green when in contact with C. rosea and E. nigrum. The mycelium pigmentation of D. pseudoseriata only did not change when interacting with Penicillium sp. In all the other interactions, the colonies of $D$. pseudoseriata changed from light to dark brown. In the interaction between P. fastigiata and the endophyte, only Trichoderma sp. did not affect the pathogen's mycelial pigmentation. The colors of the P. fastigiata colonies changed to dark brown in the interaction with the other endophytes. During interspecific mycelial interactions, changes in mycelium pigmentation of Colletotrichum acutatum in the contact zone with E. nigrum, Aspergillus brasiliensis, and Aspergillus sp. colonies were observed. The formation of pigments in the fungi mycelium can be a mechanism of the pathogen to protect hyphae from the antagonistic fungi by preventing access by cell wall degrading enzymes [90].

\section{Conclusions}

Grapevine endophytic community can have a wide range of fungi diversity, as shown in the present study using some GTDs' asymptomatic and symptomatic grapevines in the Alentejo region. It is important to reinforce the idea that we are considering endophytes as fungi that reside in the plant tissues without causing any effect on the host. Nevertheless, when the environmental conditions become favorable to them, some endophytes may also exhibit pathogenic activity. Penicillium sp. and Trichoderma sp. were the fungi with the highest number of isolates, showing more isolates in asymptomatic than in symptomatic plants. This strongly agrees with their antagonistic role, protecting plants against pathogenic fungi.

Endophyte fungi were identified in roots, petioles, and offshoots, with offshoots presenting the highest number of isolates. Among the fungi identified, nine were associated with GTDs phytopathogens. It was verified that Diaporthe sp., Neofusicoccum sp., and H. viticola were the prevalent GTDs-associated fungi in symptomatic plants, although they were also identified in asymptomatic plants. H. viticola was the prevalent fungus verified in the samples, mainly in asymptomatic plants; however, its role in the GTDs complex has not been much explored yet. The presence of GTDs-associated fungi in asymptomatic plants corroborates the statements that they can also survive, part of their lives, as endophytes without causing any symptoms to the host, which can also explain the long latency time of the diseases. The great incidence of GTDs-associated fungi in different organs of the plants (roots, petioles, and offshoots) demonstrates that those pathogens are easily spread in the plant and in the vineyard. 
Furthermore, some fungal genus/species with characteristics of biological antagonists were identified, and their antagonist activity was verified through direct inhibition. All endophytic fungi tested in the endophyte/pathogen interaction presented the inhibition of pathogens' mycelia growth, verified by competition for nutrients and space. F. oxysporum was the most effective antagonist against Diaporthe sp. and D. pseudoseriata, but it also showed an antagonistic effect against $P$. fastigiata. A. niger showed to be the most effective inhibitor of the growth of $P$. fastigiata. Penicillium sp. showed to be the less effective inhibitor against the mycelial growth of the three GTDs-associated fungi studied.

Despite the fact that the endophyte community and their role in the GTDs in the Alentejo region still need further studies, with the results here presented, we reinforce the idea that plant hosts are important sources of potential biocontrol agents against GTDs-associated fungi, and their presence seems to hold the development of GTDs symptoms in affected plants.

Author Contributions: Conceptualization, M.D.C., S.M., G.R., and M.d.R.F.; formal analysis, A.B.d.A., J.C., P.M., C.V., and M.P.; funding acquisition, S.M. and M.d.R.F.; investigation, A.B.d.A., J.C., M.D.C., P.M., C.V. and M.P.; methodology, M.D.C., S.M., G.R. and M.d.R.F.; resources, S.M. and M.d.R.F.; supervision, M.D.C., S.M. and M.d.R.F.; writing-original draft, A.B.d.A. and M.D.C.; writing-review and editing, A.B.d.A., J.C., M.D.C., P.M., C.V., M.P., S.M., G.F. and M.d.R.F. All authors have read and agreed to the published version of the manuscript.

Funding: This work was funded by the National Funds through FCT-Foundation for Science and Technology under the Project UIDB/05183/2020. M.D.C. was supported by the project "TOMVIRPROTECT" (PTDC/ASP-PLA/28266/2017 and ALT20-03-0145-FEDER 028266). P.M. was supported by the project "GAFAPROTECT" (PTDC/ASP-PLA/28263/2017 and ALT20-03-0145-FEDER-028263). Both projects were financed by the Regional Operational Program of Alentejo and Algarve supported by the FEDER and FCT/MCTES-OE. M.P. was supported by the FCT research grant SFRH/BD/145321/2019.

Conflicts of Interest: The authors declare no conflict of interest.

\section{References}

1. Gramaje, D.; Úrbez-Torres, J.R.; Sosnowski, M.R. Managing grapevine trunk diseases with respect to etiology and epidemiology: Current strategies and future prospects. Plant Dis. 2018, 102, 12-39. [CrossRef]

2. International Organisation of Vine and Wine: OIV. 2019 Statistical Report on World Vitiviniculture. Available online: http://www.oiv.int/public/medias/6782/oiv-2019-statistical-report-on-world-vitiviniculture. pdf (accessed on 3 February 2020).

3. Wines of Portugal. Available online: http://www.winesofportugal.com/br/press-room/statistics/other/ (accessed on 3 February 2020).

4. Bertsch, C.; Ramirez-Suero, M.; Magnin-Robert, M.; Larignon, P.; Chong, J.; Abou-Mansour, E.; Spagnolo, A.; Clément, C.; Fontaine, F. Grapevine trunk diseases: Complex and still poorly understood. Plant Pathol. 2012, 62, 243-265. [CrossRef]

5. Pintos, C.; Redondo, V.; Aguín, O.; Chaves, M.; Rial, C.; Mansilla, J.P. Evaluation of Trichoderma atroviride as biocontrol agent against five Botryosphaeriaceae grapevine trunk pathogens. Phytopathol. Mediterr. 2012, $51,450$.

6. Fontaine, F.; Gramaje, D.; Armengol, J.; Smart, R.; Nagy, Z.A.; Borgo, M.; Rego, C.; Corio-Costet, M. Grapevine Trunk Diseases: A Review, 1st ed.; OIV Publications: Paris, France, 2016.

7. Hofstetter, V.; Buyck, B.; Croll, D.; Viret, O.; Couloux, A.; Gindro, K. What if esca disease of grapevine were not a fungal disease? Fungal Divers. 2012, 54, 51-67. [CrossRef]

8. Claverie, M.; Notaro, M.; Fontaine, F.; Wery, J. Current knowledge on Grapevine Trunk Diseases with complex etiology: A systemic approach. Phytopathol. Mediterr. 2020, 59, 29-53.

9. Rolshausen, P.; Kiyomoto, R. The Status of Grapevine Trunk Diseases in the Northeastern United States. In Proceedings of the New England Vegetable and Fruit Conference, Manchester, NH, USA, 12-14 December 2014.

10. Bruez, E.; Lecomte, P.; Grosman, J.; Doublet, B.; Bertsch, C.; Fontaine, F.; Ugaglia, A.; Teissedre, P.; Da Costa, J.; Guerin-Dubrana, L.; et al. Overview of grapevine trunk diseases in France in the 2000s. Phytopathol. Mediterr. 2012, 52, 262-275. 
11. Dissanayake, A.J.; Liu, M.; Zhang, W.; Chen, Z.; Udayanga, D.; Chukeatirote, E.; Li, X.; Yan, J.; Hyde, K.D. Morphological and molecular characterization of Diaporthe species associated with grapevine trunk disease in China. Fungal Biol. 2015, 119, 283-294. [CrossRef]

12. Gramaje, D.; Baumgartner, K.; Halleen, F.; Mostert, L.; Sosnowski, M.R.; Úrbez-Torres, J.R.; Armengol, J. Fungal trunk diseases: A problem beyond grapevines? Plant Pathol. 2015, 65, 355-356. [CrossRef]

13. Kaplan, J.; Travadon, R.; Cooper, M.; Hillis, V.; Lubell, M.; Baumgartner, K. Identifying economic hurdles to early adoption of preventative practices: The case of trunk diseases in California winegrape vineyards. Wine Econ. Policy 2016, 5, 127-141. [CrossRef]

14. Romanazzi, G.; Murolo, S.; Pizzichini, L.; Nardi, S. Esca in young and mature vineyards, and molecular diagnosis of the associated fungi. Eur. J. Plant Pathol. 2009, 125, 277-290. [CrossRef]

15. Úrbez-Torres, J.R.; Peduto, F.; Smith, R.J.; Gubler, W.D. Phomopsis dieback: A grapevine trunk disease caused by Phomopsis viticola in California. Plant Dis. 2013, 97, 1571-1579. [CrossRef] [PubMed]

16. Chebil, S.; Fersi, R.; Bouzid, M.; Quaglino, F.; Chenenaoui, S.; Melki, I.; Durante, G.; Zacchi, E.; Bahri, B.A.; Bianco, P.A.; et al. Fungi from the Diaporthaceae and Botryosphaeriaceae families associated with grapevine decline in Tunisia. Cienc. Investig. Agrar. 2017, 44, 127-138. [CrossRef]

17. Mondello, V.; Songy, A.; Battiston, E.; Pinto, C.; Coppin, C.; Trotel-Aziz, P.; Clément, C.; Mugnai, L.; Fontaine, F. Grapevine Trunk Diseases: A Review of Fifteen Years of Trials for Their Control with Chemicals and Biocontrol Agents. Plant Dis. 2017, 102, 1189-1217. [CrossRef] [PubMed]

18. Mugnai, L.; Graniti, A.; Surico, G. Esca (black measles) and brown wood-streaking: Two old and elusive diseases of grapevines. Plant Dis. 1999, 83, 404-418. [CrossRef]

19. Andolfi, A.; Mugnai, L.; Luque, J.; Surico, G.; Cimmino, A.; Evidente, A. Phytotoxins produced by fungi associated with grapevine trunk diseases. Toxins 2011, 3, 1569-1605. [CrossRef]

20. Del Frari, G.; Cabral, A.; Nascimento, T.; Ferreira, R.B.; Oliveira, H. Epicoccum layuense a potential biological control agent of esca-associated fungi in Grapevine. PLoS ONE 2019, 14, e0213273. [CrossRef]

21. Moller, W.J.; Kasimatis, A.N. Further evidence that Eutypa armeniacae not Phomopsis viticola-Incites dead arm symptoms on grape. Plant Dis. 1981, 65, 429-431. [CrossRef]

22. Surico, G.; Mugnai, L.; Marchi, G. Older and more recent observations on esca: A critical review. Phytopathol. Mediterr. 2006, 45, 68-86.

23. Murolo, S.; Romanazzi, G. Effects of grapevine cultivar, rootstock and clone on esca disease. Australas. Plant Pathol. 2014, 43, 215-221. [CrossRef]

24. Cardot, C.; Mappa, G.; La Camera, S.; Gaillard, C.; Vriet, C.; Lecomte, P.; Ferrari, G. Coutos-Thévenot, P. Comparison of the molecular responses of tolerant, susceptible and highly susceptible grapevine cultivars during interaction with the pathogenic fungus Eutypa lata. Front. Plant Sci. 2019, 10, 991. [CrossRef]

25. Úrbez-Torres, J.R. The status of Botryosphaeriaceae species infecting grapevines. Phytopathol. Mediterr. 2011, 50, S5-S45.

26. Fleurat-Lessard, P.; Luini, E.; Berjeaud, J.M.; Roblin, G. Diagnosis of grapevine esca disease by immunological detection of Phaeomoniella chlamydospora. Aust. J. Grape Wine R. 2010, 16, 455-463. [CrossRef]

27. Halleen, F.; Fourie, P.H. An integrated strategy for the proactive management of grapevine trunk disease pathogen infections in grapevine nurseries. S. Afr. J. Enol. Vitic. 2016, 37, 104-114. [CrossRef]

28. Spinosi, J.; Févotte, J.; Vial, G. Éléments Techniques sur L'Exposition Professionnelle aux Pesticides Arsenicaux: Matrice Cultures-Expositions aux Pesticides Arsenicaux; Institut de Veille Sanitaire: Saint-Maurice, France, 2009; p. 19.

29. Landum, M.C.; Félix, M.R.; Alho, J.; Garcia, R.; Cabrita, M.J.; Rei, F.; Varanda, C.M.R. Antagonistic activity of fungi of Olea europaea L. against Colletotrichum acutatum. Microbiol. Res. 2016, 183, 100-108. [CrossRef]

30. Varanda, C.M.R.; Oliveira, M.; Materatski, P.; Landum, M.; Clara, M.I.E.; Felix, M. do R. Fungal endophytic communities associated to the phyllosphere of grapevine cultivars under different types of management. Fungal Biol. 2016, 120, 1525-1536. [CrossRef]

31. Pertot, I.; Prodorutti, D.; Colombini, A.; Pasini, L. Trichoderma atroviride SC1 prevents Phaeomoniella chlamydospora and Phaeoacremonium aleophilum infection of grapevine plants during the grafting process in nurseries. BioControl 2016, 61, 257-267. [CrossRef]

32. Petrini, O. Fungal endophytes of leaves. In Microbial Ecology of Leaves, 1st ed.; Andrews, J.H., Hirano, S.S., Eds.; Springer: Berlin/Heidelberg, Germany, 1991; pp. 179-197. 
33. Oono, R.; Lefevre, E.; Simha, A.; Lutzoni, F. A comparison of the community diversity of foliar fungal endophytes between seedling and adult loblolly pines (Pinus taeda). Fungal Biol. 2015, 119, 917-928. [CrossRef]

34. Mostert, L.; Crous, P.W.; Petrini, O. Endophytic fungi associated with shoots and leaves of Vitis vinifera, with specific reference to de Phomopsis viticola complex. Sydowia 2000, 52, 46-58.

35. Materatski, P.; Varanda, C.M.R.; Carvalho, T.; Dias, A.B.; Campos, M.D.; Rei, F.; Félix, M.R. Diversity of colletotrichum species associated with Olive Anthracnose and new perspectives on controlling the disease in portugal. Agronomy 2018, 8, 301. [CrossRef]

36. Materatski, P.; Varanda, C.M.R.; Carvalho, T.; Dias, A.B.; Campos, M.D.; Rei, F.; Félix, M.R. Spatial and temporal variation of fungal endophytic richness and diversity associated to the phyllosphere of olive cultivars. Fungal Biol. 2019, 123, 66-76. [CrossRef]

37. Varanda, C.M.R.; Materatski, P.; Landum, M.; Campos, M.D.; Félix, M.R. Fungal communities associated with peacock and Cercospora Leaf Spots in olive. Plants 2019, 8, 169. [CrossRef]

38. Musetti, R.; Polizzotto, R.; Vecchione, A.; Borselli, S.; Zulini, L.; D’Ambrosio, M.; di Toppi, L.S.; Pertot, I. Antifungal activity of diketopiperazines extracted from Alternaria alternate against Plasmopara viticola: An ultrastructural study. Micron 2007, 38, 643-650. [CrossRef] [PubMed]

39. Polizzotto, R.; D’Agostin, S.; Grisan, S.; Assante, G.; Pertot, I.; Andersen, B.; Musetti, R. Activity of endophytic Alternaria spp. strains in the control of Plasmopara viticola. Plant Pathol. J. 2009, 91, 79-80.

40. Bruez, E.; Vallance, J.; Gerbore, J.; Lecomte, P.; Da Costa, J.P.; Guerin-Dubrana, L.; Rey, P. Analyses of the temporal dynamics of fungal communities colonizing the healthy wood tissues of esca leaf-symptomatic and asymptomatic vines. PLoS ONE 2014, 9, e95928. [CrossRef]

41. Pancher, M.; Ceol, M.; Corneo, P.E.; Longa, C.M.O.; Yousaf, S.; Pertot, I.; Campisano, A. Fungal endophytic communities in grapevines (Vitis vinifera L.) respond to crop management. Appl. Environ. Microbiol. 2012, 78, 4308-4317. [CrossRef] [PubMed]

42. Fourie, P.H.; Halleen, F.; van der Vyver, J.; Schrueder, W. Effect of Trichoderma treatments on the occurrence of decline pathogens on the roots and rootstocks of nursery plants. Phytopathol. Mediterr. 2001, 40, 473-478.

43. Doyle, J.J.; Doyle, J.L. A rapid DNA isolation procedure for small quantities of fresh leaf tissue. Phytochemical $1987,19,11-15$.

44. White, T.J.; Bruns, T.; Lee, S.; Taylor, J. Amplification and direct sequencing of fungal ribosomal RNA genes for phylogenetics. In PCR Protocols: A Guide to Methods and Applications, 1st ed.; Innis, M.A., Gelfand, D.H., Sninsky, J.J., White, T.J., Eds.; Academic Press, Inc.: New York, NY, USA, 1989; pp. 315-322.

45. Dennis, C.; Webster, J. Antagonistic properties of species groups of Trichoderma III, Hyphal Interaction. Trans. Brit. Mycol. Soc. 1971, 57, 363-369. [CrossRef]

46. Nunez-Trujillo, G.; Cabrera, R.; Burgos-Reyes, R.; Da Silva, E.; Gimenez, C.; Cosoveanu, A.; Brito, N. Endophytic fungi from Vitis vinifera L. isolated in Canary Islands and Azores as potential biocontrol agents of Botrytis cinerea Pers.:Fr. J. Hortic. For. Biotechnol. 2012, 16, 1-6.

47. Haleem, R.A.; Saedo, K.A.; Abdullah, S.K. Antagonism of Trichoderma harzianum and Clonostachys rosea against fungi associated with grapevine decline in Kurdistan region-Iraq. J. Univ. Zakho. 2016, 4, 166-172. [CrossRef]

48. Boughalleb-M'Hamdi, N.; Salem, I.B.; M'Hamdi, M. Evaluation of the efficiency of Trichoderma, Penicillium, and Aspergillus species as biological control agents against four soil-borne fungi of melon and watermelon. J. Biol. Pest Co. 2018, 28, 25. [CrossRef]

49. Nusaibah, S.A.; Musa, H. A Review report on the mechanism of Trichoderma spp. as biological control agent of the Basal Stem Rot (BSR) disease of Elaeis guineensis. In Trichoderma-The Most Widely Used Fungicide, 1st ed.; Mohammad, M.S., Sharif, U., Buhari, T.R., Eds.; IntechOpen: London, UK, 2019; pp. 79-90.

50. Royse, D.; Ries, S. The influence of fungi isolated from peach twigs on the pathogenicity of Cytospora cincta. Pyhtopathology 1977, 68, 603-607. [CrossRef]

51. Clarke, K.R.; Green, R.H. Statistical design and analysis for a "biological Effects" study. Mar. Ecol. Prog. Ser. 1988, 46, 213-226. [CrossRef]

52. Clarke, K.; Warwick, R. Marine Communities: An Approach to Statistical Analysis and Interpretation, 2nd ed.; PRIMER-E: Plymouth, UK, 2001.

53. Anderson, M.J.; Gorley, R.N.; Clarke, K.R. Permanova+ for Primer: Guide to Software and Statistical Methods, 1st ed.; PRIMER-E: Plymouth, UK, 2008; p. 214. 
54. Porras-Alfaro, A.; Liu, K.L.; Kuske, C.R.; Xiec, G. From Genus to Phylum: Large-Subunit and Internal Transcribed Spacer rRNA Operon Regions Show Similar Classification Accuracies Influenced by Database Composition. Appl. Environ. Microbiol. 2014, 80, 829-840. [CrossRef] [PubMed]

55. Raja, H.A.; Miller, A.N.; Pearce, C.J.; Oberlies, N.H. Fungal identification using molecular tools: A primer for the natural products research community. J. Nat. Prod. 2017, 80, 756-770. [CrossRef]

56. Nilsson, R.H.; Abarenkov, K.; Larsson, K.-H.; Kõljalg, U. Molecular Identification of Fungi: Rationale, Philosophical Concerns, and the UNITE Database. Open Appl. Informat J. 2014, 5, 81-86. [CrossRef]

57. Pacifico, D.; Squartini, A.; Crucitti, D.; Barizza, E.; Lo Schiavo, F.; Muresu, R.; Carimi, F.; Zottini, M. The role of the endophytic microbiome in the grapevine response to environmental triggers. Front. Plant Sci. 2019, 10, 1256. [CrossRef]

58. Niem, J.M.; Billones-Baaijens, R.; Stodart, B.; Savocchia, S. Diversity Profiling of Grapevine Microbial Endosphere and Antagonistic Potential of Endophytic Pseudomonas Against Grapevine Trunk Diseases. Front. Microbiol. 2020, 11, 1-19. [CrossRef]

59. Cosoveanu, A.; Gimenez-Mariño, C.; Cabrera, Y.; Hernandez, G.; Cabrera, R. Endophytic fungi from grapevine cultivars in Canary Islands and their activity against phytopatogenic fungi. Int. J. Agri. Crop Sci. 2014, 7, 1497-1503.

60. Yadav, A.; Yadav, K. Exploring the potential of endophytes in agriculture: A minireview. Adv. Plants Agric. Res. 2017, 6, 1-5. [CrossRef]

61. Nicoletti, R.; Fiorentino, A.; Scognamiglio, M. Endophytism of Penicillium Species in Woody Plants. Open Mycol. J. 2014, 8, 1-26. [CrossRef]

62. Fischer, M. A new wood-decaying basidiomycete species associated with esca of grapevine: Fomitiporia mediterranea (Hymenochaetales). Mycol. Prog. 2002, 1, 315-324. [CrossRef]

63. Úrbez-Torres, J.R.; Adams, P.; Kamas, J.; Gubler, W.D. Identification, Incidence, and Pathogenicity of Fungal Species Associated with Grapevine Dieback in Texas. Am. J. Enol. Vitic. 2009, 60, 497-507.

64. Crous, P.W.; Wingfield, M.J.; Guarro, J.; Hernández-Restrepo, M.; Sutton, D.A.; Acharya, K.; Barber, P.A.; Boekhout, T.; Dimitrov, R.A.; Duenas, M.; et al. Fungal Planet description sheets: 320-370. Persoonia 2015, 34, 167-266. [CrossRef] [PubMed]

65. Guarnaccia, V.; Groenewald, J.Z.; Woodhall, J.; Armengol, J.; Cinelli, T.; Eichmeier, A.; Ezra, D.; Fontaine, F.; Gramaje, D.; Gutierrez-Aguirregabiria, A.; et al. Diaporthe diversity and pathogenicity revealed from a broad survey of grapevine diseases in Europe. Persoonia 2018, 40, 135-153. [CrossRef] [PubMed]

66. Rossman, A.Y.; Adams, G.C.; Cannon, P.F.; Castlebury, L.A.; Crous, P.W.; Gryzenhout, M.; Jaklitsch, W.M.; Mejia, L.C.; Stoykov, D.; Udayanga, D.; et al. Recommendations of generic names in Diaporthales competing for protection or use. IMA Fungus 2015, 6, 145-154. [CrossRef] [PubMed]

67. Van Niekerk, J.M.; Crous, P.W.; Groenewald, J.Z.E.; Fourie, P.H.; Halleen, F. DNA phylogeny, morphology and pathogenicity of Botryosphaeria species on grapevines. Mycologia 2004, 96, 781-798. [CrossRef] [PubMed]

68. Barba, P.; Lillis, J.; Luce, R.S.; Travadon, R.; Osier, M.; Baumgartner, K.; Wilcox, W.F.; Reisch, B.I.; Cadle-Davidson, L. Two dominant loci determine resistance to Phomopsis cane lesions in F1 families of hybrid grapevines. Theor. Appl. Genet. 2018, 131, 1173-1189. [CrossRef] [PubMed]

69. Arzanloua, M.; Narmania, A.; Mosharib, S.; Khodaeia, S.; Babai-Aharia, A. Truncatella angustata associated with grapevine trunk disease in northern Iran. Arch. Phytopathol. Pflanzenschutz 2013, 46, 1168-1181. [CrossRef]

70. Cole, G.T.; Kendrick, B. Taxonomic Studies of Phialophora. Mycologia 1979, 65, 661-668. [CrossRef]

71. Travadon, R.; Lawrence, D.P.; Rooney-Latham, S.; Gubler, W.D.; Wilcox, W.F.; Rolshausend, P.E.; Baumgartner, K. Cadophora species associated with wood-decay of grapevine in North America. Fungal Biol. 2014, 119, 53-66. [CrossRef] [PubMed]

72. Lawrence, D.P.; Travadon, R.; Pouzoulet, J.; Rolshausen, P.E.; Wilcox, W.F.; Baumgartner, K. Characterization of Cytospora isolates from wood cankers of declining grapevine in North America, with the descriptions of two new Cytospora species. Plant Pathol. 2016, 66, 713-725. [CrossRef]

73. Kusari, S.; Hertweck, C.; Spiteller, M. Chemical ecology of endophytic fungi: Origins of secondary metabolites. Chem. Biol. 2012, 19, 792-798. [CrossRef] [PubMed]

74. Agrios, G. Plant Pathology, 5th ed.; Elsevier Academic Press: Burlington, VT, USA, 2005; p. 992.

75. Aly, A.; Debbab, A.; Proksvch, P. Fungal endophytes: Unique plant inhabitants with great promises. Appl. Microbiol. Biotechnol. 2011, 90, 1829-1845. [CrossRef] [PubMed] 
76. Gonzalez, V.; Tello, M. The endophytic mycota associated with Vitis vinifera in central Spain. Fungal Divers. 2011, 47, 29-42. [CrossRef]

77. Udayanga, D.; Castlebury, L.A.; Rossman, A.Y.; Chukeatirote, E.; Hyde, K.D. Insights into the genus Diaporthe: Phylogenetic species delimitation in the D. eres species complex. Fungal Divers. 2014, 67, $203-229$. [CrossRef]

78. Sessa, L.; Abreo, E.; Lupo, S. Diversity of fungal latent pathogens and true endophytes associated with fruit trees in Uruguay. J. Phytopathol. 2018, 166, 633-647. [CrossRef]

79. Phillips, A.J.L. Botryosphaeria dothidea and other fungi associated with excoriose and dieback of grapevines in Portugal. J. Phytopathol. 1998, 146, 327-332. [CrossRef]

80. Pouzoulet, J.; Mailhac, N.; Couderc, C.; Besson, X.; Daydé, J.; Lummerzheim, M.; Jacques, A. A method to detect and quantify Phaeomoniella chlamydospora and Phaeoacremonium aleophilum DNA in grapevine-wood samples. Appl. Microbiol. Biotechnol. 2013, 97, 10163-10175. [CrossRef]

81. Makatini, G.; Mutawila, C.; Halleen, F.; Mostert, L. Grapevine sucker wounds as infection ports for trunk disease pathogens. Phytopathol. Mediterr. 2014, 53, 573.

82. Heydari, A.; Pessarakli, M. A review on biological control of fungal plant pathogens using microbial antagonists. J. Biol. Sci. 2010, 10, 273-290. [CrossRef]

83. Sezões, F.F.L. Endophytic fungi present in grapevines (Vitis vinifera L.) with the ability to inhibit the growth of the causal agent of black rot (Guignardia bidwellii). Master's Thesis, University of Evora, Evora, Portugal, 2016.

84. Highet, A.S.; Nair, N.G. Fusarium oxysporum associated with grapevine decline in the Hunter Valley. Aust. J. Grape Wine Res. 2008, 1, 48-50. [CrossRef]

85. Vilvert, E.; Costa, M.D.; Cangahuala-Inocente, G.C.; Lovato, P.E. Root proteomic analysis of grapevine rootstocks inoculated with Rhizophagus irregularis and Fusarium oxysporum f. sp. herbemontis. Rev. Bras. Ciênc. Solo 2017, 41, 1-14. [CrossRef]

86. Nicoletti, R.; De Stefano, M. Penicillium restrictum as an antagonist of plant pathogenic fungi. Dyn. Biochem. Process. Biotechnol. Mol. Biol. 2012, 6, 61-69.

87. Hajieghrari, B.; Torabi-Giglou, M.; Mohammadi, M.R.; Davari, M. Biological potential of some Iranian Trichoderma isolates in the control of soil borne plant pathogenic fungi. Afr. J. Biotechnol. 2008, 7, 967-972.

88. Murolo, S.; Concas, J.; Romanazzi, G. Use of biocontrol agents as potential tools in the management of chestnut blight. Biol. Control 2019, 132, 102-109. [CrossRef]

89. Martini, M.; Musetti, R.; Grisan, S.; Polizzotto, R.; Borselli, S.; Pavan, F.; Osler, R. DNA-dependent detection of the grapevine fungal endophytes Aureobasidium pullulans and Epicoccum nigrum. Plant Dis. 2009, 93, 993-998. [CrossRef]

90. Preto, G.; Martins, F.; Pereira, J.A.; Baptista, P. Fungal community in olive fruits of cultivars with different susceptibilities to anthracnose and selection of isolates to be used as biocontrol agents. Biol. Control 2017, 110, 1-9. [CrossRef]

Publisher's Note: MDPI stays neutral with regard to jurisdictional claims in published maps and institutional affiliations.

(C) 2020 by the authors. Licensee MDPI, Basel, Switzerland. This article is an open access article distributed under the terms and conditions of the Creative Commons Attribution (CC BY) license (http://creativecommons.org/licenses/by/4.0/). 